Ankara Üniversitesi Türk Inkllâp Tarihi Enstitüsü Atatürk Yolu Dergisi

S 46, Güz 2010, s. 425-455

\title{
Eskişehir Mutasarrıfı Hilmi Bey’in Öldürülmesi
}

\author{
Yrd. Doç. Dr. Zafer KOYLU*
}

\section{$\ddot{O z e t}$}

Milli Mücadele sürecinde Anadolu'daki birçok kentin yöneticisi Kuva-yı Milliye ile İstanbul Hükümeti arasında kaldı. Büyük bir kısmı çok kısa sürede var olan durumu kavrayıp Millicilerin yanına geçerken, çok azı İstanbul yanlısı tutumunu son ana kadar sürdürdü. Bunlardan biri de Eskişehir Mutasarrıfi Hilmi Bey'di. Dördüncü Damat Ferit Kabinesi döneminde Eskişehir'e Mutasarrlf atanan Hilmi Bey, ateşli bir Kuva-yı Milliye muhalifiydi.

Mondros Mütarekesi sonrasında Ingilizler demiryolu hattı güzergâhını işgale başlayınca, Eskişehir'de stratejik önemi nedeniyle işgal edildi. Mutasarrıf Hilmi Bey, bu süreçte gerek kentte yeni kurulmaya çalışılan 5. Kolordu ve onun komutanı Kiraz Hamdi Paşa, gerekse bölgedeki Itilaf Kuvvetleri komutanı ile Kuva-yı Milliye'ye karşı işbirliği yaptı.

Kentteki Kuva-yı Milliye örgütlenmesini engelleyebilmek için yetkisini aşarak sıkıönetim bile ilan eden Mutasarrıf Hilmi Bey, 4 Ekim 1919’da öğle yemeği için evine giderken öldürüldü. Hükümet olayın soruşturulması için Adliye ve Mülkiye Müfettişleri görevlendirdi. Bölgedeki Kuva-yı Milliye Komutanlığl ve Heyet-i Temsiliye de var olan durumu eleştirdi. Ancak, yapılan araştırmalara ră̆men cinayetin faili belirlenemedi.

Anahtar Kelimeler: Mutasarrıf Hilmi Bey, Eskişehir, Kuva-yı Milliye, Milli Mücadele.

* Eskişehir Osmangazi Üniversitesi Fen-Edebiyat Fakültesi Tarih Bölümü Meşelik Yerleşkesi 26480 Eskişehir, zkoylu@ogu.edu.tr 


\title{
Murder of Hilmi Beg, Mutasarrıf of Eskişehir
}

\begin{abstract}
Many urban leaders of the Turkish National War of Independence were sequeezed between national forces and the Istanbul Governmont in their fight against enemy forces. Soon afterward, however, most of them recognized the very nature of the situation and participated in national forces, with little supporters left in favor of Istanbul Governmont. One of the advocates of Istanbul Government was Hilmi Beg, Mutasarrif (local governor) of Eskişehir. Appointed to this position during his post in the $I V^{\text {th }}$ Damat Ferit Cabinett, he was an ardent opponent of national forces.

After the British set out to occupy the regions along the railway route in accordance with the stipulations of the armstice in force, Eskişehir, due to his strategic location, was subjected to occupation. During this occupaation, Hilmi Beg cooperated both with Kiraz Hamdi Pasha and his recently founded $5^{\text {th }}$ Army corps and the commander of the occupants in the town, against national forces.

Hilmi Beg even promulgated a martil law, an act beyond his official authority. On October 4, 1919, He was murdered on his way to home for lunch. Ottoman Government assigned civil and official inspectors to inquire the incident. The commandery of national forces in the region and the Representative Committe also protested against the incident but, in spite of extensive inquiries, the perpetrator could not be detected.
\end{abstract}

Key words: Hilmi Beg, Mutasarrlf of Eskişehir, Turkish National Forces, National War of Independence

\section{GíRiș}

Illk yerleşim tarihi eskiçağlara ${ }^{1}$ kadar uzanan Eskişehir, Berlin-Băgdat demiryolu hattının buraya ulaşıncaya kadar hem ticari hem de demografik anlamda bir gelişme gösteremedi. Bölgede eskiçağlardan yoğun bir şekilde gözlenen arkeolojik kalıntılar kente Eskişehir adının verilmesinde etkili oldu $^{2}$. Demiryolunun ${ }^{3}$ kente ulaşması ile birlikte Eskişehir'in stratejik önemi

\footnotetext{
${ }^{1}$ Besim Darkot, “ Eskişehir ”, İslam Ansiklopedisi, Milli Eğitim Bakanlığı Yayınları, İstanbul:1964, s.384.

2 Gaye Ertin, Eskişehir Kentinde Yerleşmenin Evrimi, Anadolu Üniversitesi Yayınları, Eskişehir: 1994, s.11; “Eskişehir”, Yurt Ansiklopedisi, c.4, Anakra:1968,s.2834; Yusuf Oğuzoğlu-Feridun Emecan, “ Eskişehir ”, Türkiye Diyanet Vakfi İslam Ansiklopedisi, Türkiye Diyanet Araştırmaları Merkezi, İstanbul: 1995, s.398;
} 
arttı ${ }^{4} 1914$ yılında yapılan idari düzenleme sırasında Eskişehir sosyal ve ekonomik gelişme göz önüne alınarak sancak merkezi haline getirildi. 4 Nisan 1915'te bağımsız bir mutasarrıflık oldu'.

I. Dünya Savaşı sırasında ise padişahın ve hükümetin geçici olarak İstanbul'dan Eskişehir'e taşınması düşünüldü. Padişah ve yakın çevresi için kentte uygun konutlar hazırlandl. Ancak Çanakkale cephesindeki savaşın başarlyla sonuçlanması üzerine bu girişime gerek kalmadı ${ }^{6}$.

Milli Mücadele başında merkezi idare şu yönetim birimlerinden oluşuyordu? :

1- Vilayet: Bu günkü il karşılığıdır. Vilayetlerin başında en büyük mülki amir olarak vali bulunmaktadır.

2- Liva: Vilayet ile kaza arası bir idari bölünmedir. Livaların başında mülki amir olarak mutasarrlf bulunmaktadır. Bu yüzden livalara mutasarrlflikta denilmektedir. 1864 tarihli Vilayet Nizamnamesi'nden kalma bir alışkanlıkla Liva karşıllğ "Sancak" kelimesi de kullanılmaktadır. Mutasarrıflıklara Livalar iki kisımdır:

Celal İnce, Eskişehir Çevre İncelemesi, İstanbul: 1969,s.58

${ }^{3}$ Demiryollarının Osmanlı Devletinde yapımı, borçlanmalar vs ile ilgili bkz.Edward Mead Earle, Bağdat Demiryolu Savaşı, (Çev: Kasım Yargıcı), Milliyet Yayınları, İstanbul: 1972; Donald Quataert, Osmanlı Devleti'nde Avrupa İktisadi Yayılımı ve Direniş ( 18811908 ), (Çev. Sabri Tekay), Yurt Yayınları, Ankara:1987; Donald Quataert, "19. Yüzyılda Osmanlı İmparatorluğu'nda Demiryolları" Tanzimattan Cumhuriyete Türkiye Ansiklopedisi, c. 6, İletişim Yayınları, İstanbul:1985; Osmalı'dan Cumhuriyet Türkiye'sine İşçiler 1839-1950, (Derleyenler: D. Quataert-E.J. Zürcher), (Çev. Cahide Ekiz), İletişim Yayınları, İstanbul:1988; Vahdettin Engin, Rumeli Demiryolları, Eren Yayınları, İstanbul:1993; Orhan Kurmuş, Emperyalizmin Türkiye’ye Girişi, (3. Bask1), Savaş Yayınları, Ankara: 1982; Lothar Rothaman, Berlin-Bağdat, Alman Emperyalizminin Türkiye'ye Girişi, (Haz: Ragıp Zarakolu), Belge Yayınları, İstanbul:1982; Murat Özyüksel, Anadolu ve Bağdat Demiryolları, Arba Yayınları, İstanbul: 1988.

${ }^{4}$ İstanbul-Eskişehir Tren seferleri 19 Haziran 1892 de başlamıştır. Ayrıntılı bilgi için bkz. Ayla Efe, Eskişehir Demiryolu, (Basılmamış Yüksek Lisans Tezi), Anadolu Üniversitesi Sosyal Bilimler Enstitüsü, Eskişehir: 1998, s.53

${ }^{5}$ Başbakanlık Osmanlı Arşivi ( BOA ) İrade-i Umûmiye (İ. UM.), Dosya No:45-1, Gömlek No: 1'den aktaran Eskișehir Sancağı Genel Meclis Kararları 1331(1915) 1332(1916) - 1333(1917) (Yayına Hazırlayan:Kemal Yakut-Şaduman Halıcı), Eskişehir Büyükşehir Belediyesi Yay., 2009, s. VII.

${ }^{6}$ Cumhuriyetin 15. Yılında Eskişehir, İstanbul: 1938, s.32; Ali Fuad Türkgeldi, Görüp İşittiklerim, TTK, Ankara:1987, s.117.

${ }^{7}$ Kâmil Erdeha, Milli Mücadelede Vilayetler ve Valiler, Remzi Kitabevi, İstanbul 1975, s. 41-42 
a-Mülhak Livalar: Bunlar vilayetlere bağlı livalardı ve mutasarrıfları validen emir alırdl.

b-Müstakil Livalar: Bu livalar doğrudan doğruya Dahiliye Nezareti'ne bağllydılar ve mutasarrıflarl da valininkine benzer bir statüde idi.

Idari taksimatta bunları Kaza, Nahiye ve Karye takip etmekteydi.

Eskişehir Sancă̆l kurulduktan sonra, buraya atanan mutasarrıflardan Zekai Bey kentin gelişmesine önemli katkılar sağladı. Girişimci bir kişiliğe sahip olan Zekai Bey, İtihat ve Terakki'nin programina uygun çalı̧̧malar yaptı. Eskişehir'deki görevi sürecinde 1918'de Eskişsehir Çiftçi Bankası'nın kuruluşunda faal rol oynadl. Daha sonra Mutasarrıflı görevine Sami Bey getirildi ${ }^{8}$. Ancak belediye başkanlı̆̆ maaşı ile ortaya çıkan sorunlar nedeniyle Sami Bey'in başkandan yana tavır alması üzerine Dahiliye Nezareti tarafindan görevinden alınarak başka bir yere tayin edildi. Mutasarıflı̆̆a Ertuğrul Şakir Bey vekaleten getirildi ${ }^{9}$

Bu dönemde Mondros Mütarekesi ile Osmanl Devleti'ne birakulan bu topraklar üzerinde: 15 vilayet, 35 mülhak liva, 17 müstakil liva bulunuyordu ${ }^{10}$. Eskişehir livası da bu müstakil livalardan biriydi.

\section{A- Eskişehir'in İngilizler Tarafından İşgali ${ }^{11}$}

Osmanlı Devleti Birinci Dünya savaşından yenik çıkarak 30 Ekim 1918 'de Mondros Mütarekesi'ni imzalad1' ${ }^{12}$. I.Dünya Savaşı'nın galipleri savaş içerisinde yapılan gizli anlaşmalar ${ }^{13}$ doğrultusunda belirledikleri

${ }^{8}$ Zafer Koylu, "XX. Yüzyılın Başlarında Eskişehir”, Atatürk Araştırma Merkezi Dergisi, c. XXIV, Temmuz 2008, Say1: 71, s. 384-385.

${ }^{9}$ B.O.A., DH., Umur-ı Mahalliye Vilâyat Müdüriyeti (UMVM), Dosya No: 93, Vesika No: 55/4, 1-2'den, İhsan Güneş-Kemal Yakut, Osmanlı'dan Cumhuriyet'e Eskişehir (1840-1923), Anadolu Üniversitesi Yayınları No: 1724, Edebiyat Fakültesi yayınları No: 25, Eskişehir 2007, s. 23-24.

${ }^{10}$ Erdeha, a.g.e., s. 44.

11 Ayrıntılı bilgi için bkz., Zafer Koylu, Esaretten Özgürlüğe 423 Gün (İngiliz İşgalinde Eskişehir), Eskişehir Ticaret Odası Yayınları, Eskişehir 2010.

${ }^{12}$ Muzaffer Erendil, “Atatürkçü Uygulamada Milli Güç”, Atatürk Araştırma Merkezi Dergisi, c. V, Mart 1989, S. 14, s.355.

${ }^{13}$ Gizli Anlaşmalar ile ilgili ayrıntılı bilgi için bkz. Yuluğ Tekin Kurat, Osmanlı İmparatorluğu'nun Paylaşılması, Ekonomik ve Sosyal Araştırmalar: 8, Turhan Kitabevi: Ankara 1986; Ahmet Hurşit Tolon, Birinci Dünya Savaşı Sırasında Taksim Anlaşmaları ve Sevr'e Giden Yol, Atatürk Araştırma Merkezi, Ankara:2004; Osman Olcay, Sevr Antlaşmasına Doğru (Çeşitli Konferans ve Toplantıların Tutanakları ve Bunlara ilișkin Belgeler), Ankara Üniversitesi Siyasal Bilgiler Fakültesi Yayınları No: 455, Ankara: 1981. 
yerleri, bunlara bitişik sahaları ve demiryolu hattı üzerindeki kesişme noktalarını Mondros Ateşkes Antlaşması'nın 7. ve 15. maddesine dayanarak ${ }^{14}$ işgale başladı.

Mondros Mütarekesi'nin yapıldığı sırada, Mustafa Kemal Paşa, Yıldırım Orduları Grup Kumandanı olarak Adana'da bulunmaktayd1. Mütarekeden bir hafta sonra bir İrade-i Seniyye ile Yıldırım Orduları Grubu ve 7. Ordu Karargâhı lağvedildi, Mustafa Kemal Paşa Harbiye Nezareti emrine alındı. Ulusal Kurtuluş Savaşı'nın müstakbel lideri, kendisine bağlı kumandanlıklara ve Adana Valiliğine bir genelge ile veda ederek İstanbul'a hareket etti ${ }^{15}$

3 Kasım1918 ile 13/16 Nisan 1919 tarihleri arasında İngilizler ve Fransızlar Anadolu'nun büyük bir bölümünü ișgal ettiler ${ }^{16}$. Bu durum onların müttefiki olan İtalya ve Yunanistan'1 harekete geçirdi. Bu iki devlette gerek gizli anlaşmalarda, gerekse barış konferanslarında istenilen ya da vaadedilen bölgeleri işgale başladı.

Kara ve demiryolları ile Ankara'ya uzanan telgraf hattı üzerinde bulunan Eskișehir'in konumu, ciddi bir stratejik değer taşımaktaydı. Çünkü Eskişehir, İstanbul'dan Ankara'ya uzanan demiryolu hattı üzerinde önemli bir duraktı. Diğer yandan Afyonkarahisar üzerinden Konya ve İzmir'e uzanan demiryolu hatları da Kütahya yolu ile Eskişehir'e bağlanmaktaydı. Böylece her üç demiryolu hattını birbirine bağlayan önemli bir kavşak

14 "Yedinci Madde: Müttefikler emniyetlerini tehdit edecek vaziyet zuhurunda herhangi stratejik noktasını işgal hakkını haiz olacaklardır."

"On beşinci Madde: Bilcümle hutut-u hadidiyeye (bütün demiryolu hatlarına )itilâf murakabe (kontrol) subayları memur edilecektir. Bunlar meyanında elyevm Hükûmeti Osmaniye'nin murakebesi altında bulunanMavera-y1 Kafkas hutut-u hadidiyesi aksamı dahildir. İş bu Kafkas hututu serbest ve tam olarak İtilâf memurlarının idaresi altında vaz'edecektir. Ahâlinin ihtiyacının tatmini dikkat nazarına alınacaktır. İş bu maddeye Batum'un işgali dahildir. Osmanlı Hükûmeti Bakü’nün işgaline itirazda bulunmayacaktır." Türk İstiklal Harbi I, Mondros Mütarekesi ve Tatbikatı, TC. Genelkurmay Başkanlığı Yayını, Ankara: 1999, s. 47

${ }^{15}$ Sabahattin Selek, Milli Mücadele, c.I, Örgün Yayınları, İstanbul: 1982, s. 120.

163 Kasım 1918'de başlayan İngiliz işgali ile Musul, Çanakkale Boğazı (Fransızlarla birlikte), İskenderun, Antakya, Batum, Kilis, Ankara İstasyonu, Ayıntap, Cerablus, Haydarpaşa İstasyonu, Konya istasyonu, Maraş, Birecik, Samsun, Harapnaz ve Telebiyaz İstasyonları, Urfa, Merzifon, Kars vb yerler olmak üzere Anadolu'nun büyük bir bölümünü kapsamaktaydı. Selek, a.g.e., c.I, s.106, 188-189; Mehmet Şahingöz, İzmir, Maraş ve İstanbul'un İşgali Üzerine Yapılan Protesto ve Mitingler, Ankara Üniversitesi Türk İnkılâp Tarihi Enstitüsü, Yayınlanmamış Doktora Tezi, Ankara, 1986, s.21. 
durumundayd ${ }^{17}$. İngilizler 18 Ocak 1919 'dan itibaren demiryolu hatt1 üzerindeki İzmit, Eskișehir ve Afyonkarahisar' a kontrol birlikleri göndermeye başladi ${ }^{18} .22$ Ocak 1919'da bir İngiliz birliği Eskişehir'e geldi ${ }^{19}$ ve stratejik önemi bulunan Eskişehir istasyonunu fiilen işgal etti ${ }^{20} . \mathrm{Bu}$ tarihten sonra İngilizler, demiryolu hattındaki birliklerini takviye amacıyla belirli aralıklarla asker sevkıyatını sürdürdü ${ }^{21}$. Osmanlı Hükümeti halkın tepki göstermesini engellemek için, bu hareketin bir işgal olarak algılanmamasını, salt demiryollarının denetimine yönelik bir eylem olarak değerlendirilmesini istedi. Ancak İngilizler halkın gururunu inciten sorunlar çıkartmada gecikmediler. Olayların giderek artış göstermesi üzerine şikâyetler İstanbul'a kadar ulaştı. Bunun üzerine Dâhiliye Nezareti Eskişehir Mutasarrıflığına gönderdiği gizli kayıtlı telgrafla bölgede olay çıkarılmamasını ve İtilaf Devletleri'nin kızdırılmamasını istedi ${ }^{22}$.

15 Mayıs 1919 'da İzmir'in Yunan kuvvetlerince işgali ${ }^{23}$ ve müthiş bir vahşetin $^{24}$ başlatılması üzerine ${ }^{25}$ tüm yurtta olduğu gibi Eskişehir'de de protesto gösterileri yapıldı. 17 Mayıs 1919 günü Odunpazarı meydanında toplanan on bin kişinin katıldığı büyük bir mitingle işgal protesto edildi.

17 İsmail Yıldırım, Milli Mücadele’nin Bașlangıcında Eskișehir ( 22 Ocak 1919-20 Mart 1920 ), Eskişehir Büyükşsehir Belediyesi Yayını, Eskişehir:1998, s.19

${ }^{18}$ Askeri Tarih ve Stratejik Etüdler Arşivi(ATASE), İSH, Kutu No: 250, Gömlek No: 81; ATASE Arşivi, Klasör No:238, Dosya no: 17-11, Fihrist no: 19-1'den aktaran Ali Sarıkoyuncu-Selahattin Önder-Mesut Erşan, Milli Mücadelede Eskişehir, Osmangazi Üniversitesi Yayınları, Yayın No: 072, s. 7.

${ }^{19}$ Zeki Saruhan, Kurtuluş Savaşı Günlüğ̈̈, c. I, Ankara:1986, s. 111.

${ }^{20}$ Yıldırım, a.g.e., s. 19-20; Tayyib Gökbilgin, Milli Mücadele Başlarken, c. I, Ankara: 1985, s. 3. Sabahattin Selek, Milli Mücadele, c. I, Ankara, 1982, s. 67-70; Sarkoyuncu., vd., a.g.e., s. 7.

${ }^{21}$ Bunlar arasında Hintli askerler çoğunluktaydı Genkur. ATASE Arşivi, İSH, Kutu No: 47, Gömlek No: 146; Bu Hintli askerler belli bir müddet sonrasında da Afyonkarahisar'a sevk edilmiştir. Bkz. Genkur. ATASE Arşivi, İSH-3A, Sıra No: 4386, Kutu No: 97, Gömlek No: 132.

${ }^{22}$ BOA., DH. ŞFR., Dn. 97, Vn. 12,

${ }^{23}$ Zeki Sarıhan, Kurtuluş Savaşı Günlüğü, c.I, Öğretmen Dünyası Yayınları, Ankara: 1984, s. 237-2; Gothart Jaeschke, Kurtuluş Savaşı Kronolojisi, Türk Tarih Kurumu, Ankara: 1989, s. 32

${ }^{24}$ M. L. Smith, Anadolu Üzerindeki Göz, Hürriyet Yayınları, İstanbul: 1978, s. 101104.

${ }^{25}$ Batı Anadolu'daki Yunan vahşeti için bkz. Türkiye'de Yunan Vahşeti, ( Çev: Yrd. Doç. Dr. Necdet Ekinci ) Yeniden Anadolu Müdafaa-i Hukuk Yayınları, Antalya: 2006;Em. Kur. Alb. Talat Yalazan, Türkiye'de Yunan Vahşet ve Soy Kırımı (15 Mayıs 1919-9 Eylül 1922), c.1-2, TC. Genkur. ATASE Bşk. Yay., Genelkurmay Basım evi, Ankara:1994 
Mitingden sonra matem işareti olarak yirmi dört saat dükkânlar kapatıldı, gerekli yerlere pek çok protesto telgrafı çekildi ${ }^{26}$.

Damat Ferit Paşa hükümeti de bu tepkilerden büyük ölçüde etkilendi. Önceleri, kimi muhalefet ve saray çevreleri, kendi heyecanlarını gizleyerek olayı başka şekillerde açıklamaya çalıştılar. Ancak 16 Mayıs'ta hükümet istifa etti. İstifa kabul edilerek, yeni hükümeti kurma görevi yine Damat Ferit'e verildi ${ }^{27}$. 19 Mayıs günü hükümet kuruldu ${ }^{28}$. İzmir'in işgali sonrasında kurulan bu hükümete Damat Ferit, sandalyesiz nazırlar ekleyerek, bazı resmi bildiriler yayınlayarak, ya da İttihatçıların mahkemelerine ara vererek, tutuklu bulunan bazı gazetecileri serbest bırakarak, bazılarının da İstanbul'a dönmesine izin vererek gösterilen tepkilere katıldı ${ }^{29}$. Fakat İzmir'in işgali nedeniyle, İstanbul'un çeşitli bölgelerinde de etkili mitingler yapılmaya devam edildi ${ }^{30}$. Bu durumdan rahatsız olan yeni hükümet, 25 Mayıs'ta Beyazıt ve Beşiktaş mitinglerini yasakladı. Mustafa Kemal Paşa'nın 28 Mayıs 1919'da yayınladığı Havza Genelgesi üzerine miting yapma eylemi yeniden ivme kazand. Ancak bu durum İtilaf Devletlerini rahatsız etti. 30 Mayıs tarihli Sultanahmet'te yapılan ikinci miting sonrasında İtilaf Devletleri adına Calthorpe, 31 Mayıs'ta sadrazamdan İstanbul ve çevresinde miting izni verilmemesini istedi ${ }^{31}$. Bunun üzerine Hükümet, sarayla birlikte, tepkilerin aşırı biçimler alabileceği ve uzayıp gittiği takdirde İngilizlere yanaşma siyasetine zarar vereceği korkusuyla, kısa bir zaman sonra tepkilere karşı çıkmaya, İzmir'in işgalinden önceki yolundan yürümeye başladi. Haberleşmelerin yasaklanmasından tutuklamalara, görevden almalar ve yeni atamalara kadar birçok uygulama ${ }^{32}$ Anadolu'ya yansımada gecikmedi. Böylece İstanbul'da mitingler yasaklanırken, Anadolu'da giderek yaygınlaştı.

${ }^{26}$ İleri, 19 May1s 1335/1919, Numro: 491/109 ve Leon Rouillon, Pour La Turquie, Paris: 1921, s. 59'dan aktaran Sarkoyuncu vd., a.g.e., s.8.

${ }^{27}$ Sina Akşin, İstanbul Hükümetleri ve Milli Mücadele, c. I, İş Bankası Kültür Yayınları, Ankara: 1988, s.272.

${ }^{28}$ Akşin, a.g.e., s. 300

${ }^{29}$ Akşin, a.g.e., s. 308-311.

30 İstanbul Mitingleri için bkz. Kemal Arıburnu, Milli Mücadelede İstanbul Mitingleri, Yeni Desen Matbaası, Ankara: 1975.

${ }^{31}$ Akşin, a.g.e., s. 306-307.

${ }^{32}$ Akşin, a.g.e., s. 308-311. 


\section{B- Mustafa Hilmi Bey ve Eskişehir Mutasarrıflığı}

Mustafa Hilmi Bey, Serez ileri gelenlerinden Kocaağazade adiyla bilinen Ali Efendi'nin oğludur. 1871 yılında Serez'de ${ }^{33}$ doğdu. Serez Rüşdiyesi'nde orta öğrenimini, Mülkiye'nin İdadi kısmında Lise'yi tamamladi. Temmuz 1890'da Mülkiye'nin Yüksek kısmından 'Karibü'la'lâ" (İyiye yakın) derece ile mezun oldu. Aynı yılın Ekim ayında Serez İdadisi tarih ve hesap dersleri muallimliğine atanarak devlet hizmetine girdi. 12 Ekim 1892'de Bursa vilayeti maiyyet memurluğuna tayin edildi. Daha sonra sırasıyla Atranos (Orhaneli), Pazarköy, Kuşadası, Ödemiş, Pilmar(Midilli-Cezayir-i Bahri Sefid Vilayeti) kazaları kaymakamlarında bulundu. 3 Mayıs 1909'da Kosova Mektupçuluğu'na nakledildi. Buradan Mutasarrıflığa yükseltilerek, 1 Aralık 1909'dan itibaren Preveze, Çorum, Mardin, Hakkari, Nablus, Malatya ve Zor Sancaklarında mutasarrıflık yaptı. Birinci Dünya Savaşında Irak cephesinde başlangıçtaki başarılara rağmen Zor'un işgali üzerine bu görevinden ayrıldı. Fakat 1919 Ağustos ay1 ortalarında Eskişehir Sancağı Mutasarrıfı olarak görevlendirildi ${ }^{34}$.

Hilmi Bey Eskişehir'e geldiğinde Anadolu'da İstanbul Hükümeti ile Milliyetçi güçler arasında ciddi bir gerginlik vardı. Zira Erzurum Kongresi yapılmış, Sivas Kongresi için hazırlıklar sürüyordu. Eskişehir'deki milliyetçi güçler de bu kongreye katılabilmek için büyük bir çabanın içine girmişlerdi. Milli mücadeleye karşı olan Damat Ferit Paşa hükümeti de kendilerine bağlı olan vali, mutasarrıf ve komutanlarla milli harekâtı durdurmaya çalışıyordu.

Sivas Kongresi hazırlıkları tüm hızıyla devam ederken Eskişehir'de (Eskişehir o sırada bağımsız mutasarrıflıktı) İstanbul Hükûmetince Ali Fuat Paşa'nın yerine Ankara Kolordu Komutanlığına gönderilmiş olan Kiraz Hamdi Paşa vardı. İstanbul Hükûmeti ve Kiraz Hamdi'nin Eskişehirlileri baskı altına alıp Eskişehir'i ulusal mücadele dışında tutma çabaları sonuçsuz kald. Nitekim yurtsever Eskişehirliler ilk günden itibaren Sivas'taki ulusal hareketle ilgilenmişler ve hiç yılgınlık göstermeden üç fedakâr evladını kongreye delege olarak göndermişlerdi ${ }^{35}$. Bunlar taşocakları sahibi Siyahîzade Halil İbrahimBey(Sipahi), Tüccar Bayraktarzâde Hüseyin Bey ve askerlikten ayrılma Hüsrev Sami Bey(Kızıldoğan)d1 ${ }^{36}$.

${ }^{33}$ Serez: Osmanlı Döneminde Balkanların en önemli kentlerinden biri olup, bu gün Yunanistan sınırları içerisinde Orta Makedonya bölgesinde aynı adı taşıyan bir ildir

${ }^{34}$ Mücellidoğlu Ali Çankaya, Son Asır Türk Tarihinin Önemli Olayları ile Birlikte

Yeni Mülkiye ve Mülkiyeliler (1860-1923), c. 3, Ankara: 1968, s. 435.

${ }^{35}$ Mahmut Goloğlu, Milli mücadele Tarihi II: Sivas Kongresi, İş Bankası Kültür Yayınları, İstanbul: 2008, s. 36-37.

${ }^{36}$ Türk İstiklal Harbi II. Cilt, Batı Cephesi 2nci Kısım, s. 464 ; Suna Kili, Türk

Devrim Tarihi, İstanbul: 1962, s. 38; Goloğlu, a.g.e., s. 83; Arıburnu, a.g.e., s. 71; Ahrar, 7 Ekim 1919, Sayı: 6'dan Yıldırım, a.g.e., 
İstanbul'daki Damat Ferit Hükûmeti'nin Anadolu Ulusal hareketini engellemeye yönelik faaliyetleri kongrenin bașından sonuna kadar devam etti. Bu hareketlerin arkasındaki en önemli faktör Harbiye Nâzırı Süleyman Şefik ${ }^{37}$ ve Dahiliye Nâzırı Âdil Bey'di ${ }^{38}$. Özellikle Sivas Kongresi'nin Elazığ Valisi Ali Galip tarafından basılıp dağıtılması ve Mustafa Kemal ile arkadaşlarının tutuklanarak İstanbul'a gönderilmesi bu ikilinin planıyd1 ${ }^{39}$. Çünkü Ali Galip Bey ile Dâhiliye Nâzırı Âdil Bey arasındaki şifreli haberleşme Mustafa Kemal Paşa ve arkadaşları tarafından yakalandı. Şifreler çözümlendiğinde merkezi hükûmetin hainane planları da ortaya konuldu ${ }^{40}$

Ali Fuat Paşa'nın Eskişehir ve çevresini milli kuvvetlerle sarmak, Eskișehir'e içten ve dıștan bask1 yapmak șeklindeki hareketi ve baskısı genișledikçe hem İstanbul'un atadığı kolordu komutanı Hamdi Pașa, hem de Eskişehir Mutasarrıfı Hilmi Bey korkmaya başladı ${ }^{41}$. Çünkü Hilmi Bey'in

s. 39; Uluğ İğdemir, Sivas Kongresi Tutanakları, Türk Tarih Kurumu, Ankara:1986, s.99-105.

${ }^{37}$ İtilaf devletlerinin baskısı karşısında aciz kalan Damat Ferit Paşa, milli teşkilatlarla mücadele konusunda başarılı olmadığını düşündüğü Harbiye Nazırı Nazım Paşa'yı görevden alarak, yerine "Kuva-yı Milliye'nin hakkından ancak ben gelirim" diyen Süleyman Şefik Paşa'y1 13 Ağustos 1919'da bu göreve getirdi. O’nun bu göreve gelmesinden kısa bir süre sonra Kuva-yı Milliye'yi desteklemesinden şüphe edilen Ordu Müfettişlikleri ve ordu komutanlıkları lağvedildi. Ayrıca yayınlanan bildiri ile Osmanlı askerlerinin Kuva-yı Milliye faaliyetlerine kesinlikle iştirak etmemesi istendi. Bkz. Osman Özsoy, Saltanattan Cumhuriyete Kurtuluş Savaşı 1918-1923; Olaylar-Belgeler-Gerçekler, İstanbul Timaş Yayınları 2007, s. 182.

${ }^{38} \mathrm{Bu}$ iki kişi Milli Mücadele karşıtı faaliyetleri nedeniyle daha sonra yayınlanan 150'likler listesinde yer almıştır. Bkz. Sedat Bingöl, 150'likler Meselesi, Bir İhanetin Anatomisi, Bengi Yayınları 2010; İlhami Soysal, 150'likler Kimdiler, Ne Yaptılar, Ne Oldular?, İstanbul: Gür Yayınları 1988.

${ }^{39}$ Adil Bey'in Milli Mücadele aleyhtarı faaliyetleri için bkz. Selçuk Ural, "Ali Galip Olayının Milli Mücadele Taraftarı Gazetelerdeki (İrade-i Milliye ve Albayrak) Yankıları", Atatürk Yolu, Ankara Üniversitesi Türk İnk1lâp Tarihi Enstitüsü, S. 29-30, Mayıs-Kasım 2002, s.162-170; Haluk Selvi, "İstanbul Hükümetinin Kuva-y1 Milliye Hareketini Bölme Teşebbüsü, Jandarma Umum Kumandanı Kemal Paşa'nın Batı Anadolu Gezisi ve Sonuçları”, Atatürk Araștırma Merkezi Dergisi, Say1 44, Cilt: XV, Temmuz 1999, ss. 547-567.

${ }^{40}$ Cebesoy, a.g.e., s.194-197; Adil Bey'in Milli Mücadele aleyhtarı faaliyetleri için bkz. Selçuk Ural, “Ali Galip Olayının Milli Mücadele Taraftarı Gazetelerdeki (İrade-i Milliye ve Albayrak) Yankıları”, Atatürk Yolu, Ankara Üniversitesi Türk İnkılâp Tarihi Enstitüsü, S. 29-30, Mayıs-Kasım 2002, s.162-170; Haluk Selvi, “İstanbul Hükümetinin Kuva-y1 Milliye Hareketini Bölme Teşebbüsü, Jandarma Umum Kumandanı Kemal Paşa'nın Batı Anadolu Gezisi ve Sonuçları”, Atatürk Araştırma Merkezi Dergisi, Sayı 44, Cilt: XV, Temmuz 1999, ss. 547-567.

\footnotetext{
${ }^{41}$ Cebesoy, a.g.e., s. 98.
} 
Eskişehir'e Mutasarrıf atanmasıyla ${ }^{42}$ birlikte bölgedeki İngiliz İşgal güçleriyle de işbirliği yapılarak, kentteki Kuva-yı Milliyecilerin üzerine gidilmeye, baskılamaya ve Milli direniş tam anlamıla yok edilmeye çalışıldı ${ }^{43}$. Bu zaman sürecinde Ali Fuat Paşa'nın Eskişehir Harekâtına başlaması ve İngilizlerin bölgede bulunan kuvvetlerini artırmaya çalışmaları üzerine İzmit, Eskișehir, Kütahya, Afyonkarahisar livalarının bulunduğu eksen hem İstanbul, hem de Sivas Kongresi açısından "en kritik bölge" haline geldi. $\mathrm{Bu}$ livalarda hala İstanbul Hükümetine gönülden bağlı mutasarrıflar vardı. Eskişehir Mutasarrıfı Hilmi Bey'de bunlardan biriydi ${ }^{44}$.

Sivas Kongresi sonrasında Kongre Genel Kurulu adına 12 Eylül 1919'da bütün komutan ve valilere gönderilen ${ }^{45}$ :

"Hükümet, ulusun sevgili Padişahına dileklerini ulaştırmasını engelleyip, onunla bağlantısını kesmekte ve gerçekleşen haince davranışını sürdürmekte direndiğinden, ulus da yasal bir hükümet başa geçinceye değin İstanbul Hükümeti ile yönetim yönünden ilişkisini ve İstanbul ile her türlü telgraf ve posta haberleşme ve ulaştırmasını büsbütün kesmeye karar vermiştir. Her yerdeki sivil memurlar, askeri komutanlarla birlikte bu kararı yerine getirecek ve sonucu Kongre Genel Kuruluna bildirecektir " kararı, Mutasarrıf Hilmi Bey'e de iletildi. Ancak o bu karara uymadı.

\section{C- Mutasarrıf Hilmi Bey'in Milli Mücadele Karşıtı Faaliyetleri}

Eskişehir Mutasarrıfı Hilmi Bey, Sivas Kongresi kararlarına karşıt tavır sergilerken, Anadolu Hareketi gün geçtikçe gelişmekteydi. Kısa zamanda Sivas Genel Kongresi kararlarına sekiz vilayet, beş kolordu katıldı. Önceleri tereddüt ve direnç göstermiş olan Kastamonu, Çorum, Afyonkarahisar ve Kayseri'de Kongre Kararlarını kabul ederek İstanbul ile tüm bağlantılarını kopardı. Bu durum üzerine iktidarda bulunan Damat Ferit Paşa Hükümeti, Anadolu'daki milliyetçi asker-siviller üzerine daha şiddetli gitmeye başladı.

Siyasi $^{46}$ ve askeri atmosferin tehlikeli bir boyuta ulaşması üzerine Ali Fuat Paşa, Temmuz sonu Ağustos başı itibarıyla bazı birlikleri, " asayişi

\footnotetext{
${ }^{42}$ Hilmi Bey'in Eskişehir Mutasarrıflı̆̆ına atanması ile ilgili Ali Çankaya, 31 Ağustos 1919 tarihini verirken, Yeni Tasvir-i Efkar gazetesi 25 Ağustos 1919'da atamanın yapıldığ belirtilmektedir. Bkz. Güneş-Yakut, a.g.e., s. 170, dipnot 518.

${ }^{43}$ Güneş-Yakut, a.g.e., s. 170.

${ }^{44}$ Sarkoyuncu vd., a.g.e., s.26.

${ }^{45}$ Nutuk, a.g.e., s. 190-191

${ }^{46}$ Ankara, Konya, Afyonkarahisar, Eskişehir, Kastamonu'da valiler yada mutasarrıflar milli mücadele aleyhinde inanılmaz bir faaliyet sürdürmekteydi. Cebesoy, a.g.e., s. 223-229.
} 
sağlamak ve cephanelikleri korumak vs ${ }^{47}$ " amaçlarla Ankara'dan Eskişehir'e göndermeye başladı ${ }^{48}$.

Sivas Kongresi tarafindan "Bat1 Anadolu Umum Kuva-y1 Milliye Komutanlığı"na atanan ${ }^{49}$ Ali Fuat Paşa, nın komutasındaki Kuva-yı Milliye'nin bu hareketleri İngilizleri de harekete geçirdi ve İzmit'ten Eskişehir'e İtilaf Askerleri sevk edilmeye başlandı ${ }^{50}$. Kuva-yı Milliye güçleri, Eskişehir'e doğru çemberi daraltmaktaydı. Çünkü Eskişehir bulunduğu stratejik konum nedeniyle, hem Kuva-yı Milliye hem de İstanbul Hükümetiyle İngilizler için ciddi anlamda önem arz etmekteydi ${ }^{51}$

Ali Fuat Paşa'nın "Eskișehir Harekâtı" dan haberdar olan Eskișehir Mutasarrıfı Hilmi Bey alınacak önlemler konusunda Dâhiliye Nezareti ile yoğun bir şekilde haberleşmeye başladı.

Mutasarrıf Hilmi Bey, 13 Eylül 1919'da 190 sayılı şifre ile Dâhiliye Nezareti'ne müracaat ederek, Kuva-yı Milliye'nin Eskişehir'e girme olasılığına karşı Bölgedeki Jandarma kuvvetinin dağınık ve sayısının az olması nedeniyle, işgal kuvvetleriyle işbirliğine gidilmesini önererek, izlenecek yöntem konusunda bilgi verilmesini istedi ${ }^{52}$.

Dahiliye Nazırı ise bu telgrafa 16 Eylül 1919'da verdiği cevapta ${ }^{53}$ “ ....Demin söylediğim veçhile erbab-1 isyana karşı her türlü tedâbire müracaatla Eskişehir'in temin-i muhafazası ehem ve elzemdir. ....Tekrar ediyorum muhafaza-i memleket için kumandan ile bilmüzakere orada mevcut olan her vasitadan(İngiliz kuvvet ve askerleri kastedilmektedir)

${ }^{47}$ Genkur. ATASE Arşivi, İSH, Kutu No: 195, Gömlek No: 30; Genkur. ATASE Arşivi, İSH, Kutu No: 195, Gömlek No: 146; Genkur. ATASE Arşivi, İSH, Kutu No: 195, Gömlek No: 265.

${ }^{48}$ Genkur. ATASE Arşivi, İSH, Kutu No: 40, Gömlek No: 119; Genkur. ATASE Arşivi, İSH Kutu No: 40, Gömlek No: 128; Genkur. ATASE Arşivi, İSH, Kutu No: 40, Gömlek No: 129.

49 “20. kolordu Kumandanı Ali Fuat Paşa'nın Eskişehir ve Afyon Karahisarı fırka kumandanlarına milli harekât hakkında yazdığı emir sureti Kongrenin bu günkü toplantısında okunarak Ali Fuat Paşa'nın Batı Anadolu Umum Kuva-yı Milliye Kumandalığı'na tayin olunmasına Kongre heyetince karar verildi ve Aydın cephesine muktedir bir kumandan tayin etmesi rica olundu. Mustafa Kemal ve ayrica dokuz imza. " Bekir Sitk1 Baykal, Heyet-i Temsiliye Kararları, TTK, Ankara: 1989, s. 1-2; Atatürk'ün Bütün Eserleri, c. 3, Kaynak yayınları, İstanbul: 2000, s. 378.

${ }^{50}$ Genkur. ATASE Arşivi, İSH, Kutu No: 103, Gömlek No: 34.

${ }^{51}$ Selahattin Tansel, Mondros'tan Mudanya'ya Kadar, c.2, MEB. Yay., İstanbul: 1991, s.129.

${ }^{52}$ TíTE Arşivi., Kutu No: 21, Belge No: 16-2001; Cebesoy, a.g.e., s. 235-236.

${ }^{53}$ TİTE Arşivi., Kutu No: 21, Belge No: 16-2001. 
istifade ve her türlü tedâbire müracaat etmek lâzım geleceği bedihîdir. Neden tereddüt olunduğunu anlamıyorum" demekteydi.

Dâhiliye Nâzırı Âdil Bey, Mutasarrıf Hilmi'nin korku ve telaş içerisinde teklif ettiği önlemlerle ilgili olarak verdiği bu cevapla, her ne pahasına olursa olsun, Millicilerin ortadan kaldırılmasını istiyor, bunun icin yapılacak her şeyi mubah görüyor ve mutasarrıfa geniş yetkiler veriyordu ${ }^{54}$.

Mutasarrıf Hilmi Bey, bunlar yetmiyormuş gibi İstanbul'dan kuvvet gönderilmesi olanağı yok ise ilk yoklamaları yapılmış iki sınıfın silahlandırılmasına da izin istedi ${ }^{55}$.

Bölgedeki 20. Kolordu komutan vekili Ali Fuat Paşa, yaşanan gelişmeleri halkın birbirine düşürülmesi olarak değerlendirmekteydi ${ }^{56}$.

Mutasarrıf Hilmi Bey, 17 Eylül 1919'da, “İş iş'ar ve istifsara dökülecek olursa Mehd-i Osmaniyan olan Eskişehir'de hainlerin taarruzuna hedef olacaktır.... Müsaade buyrulursa bu günkü temayülâta göre sekene-i memleketten eli silah tutanları bile bu hainlere karşı sevketmek mümkündür, ferman $^{57}$." İçeriğindeki telgrafla da bir yandan Kuva-yı Milliyecileri ağır bir şekilde itham ederken, diğer yandan vatandaşları birbirine kırdırmanın çarelerini aramaktaydi $1^{58}$.

Aynı tarihte Ali Fuat Paşa Karargâhını Sivrihisar'dan önce Mahmudiye'ye, daha sonra Hamidiye'ye nakletti. Geçen zaman süreci içerisinde Mili Harekete katılımın giderek artması ${ }^{59}$, Sivrihisar ve Mihalıççık kazalarının kongre kararlarına bağlı olduklarını bildirmesi Mutasarrıf Hilmi ve Kiraz Hamdi'nin korkuların 1 da $\operatorname{artırd}_{1}{ }^{60}$. Bu nedenle Milli Hareketi bastırabilmek için, iç çatışmada dâhil olmak üzere her yolu denemeye başladı. Mutasarrıf Hilmi Bey'in kaotik bir ortam yaratma girişimlerinin fark edilmesi üzerine Heyet-i Temsiliye devreye girdi ve Mutasarrıf Hilmi Bey’e

${ }^{54}$ Cebesoy, a.g.e., s. 236.

${ }^{55}$ Cebesoy, a.g.e., s. 236.

56 “ Mutasarrıf Hilmi Bey, bizleri yani millîcileri kahredebilmek için evvelâ İngilizlere müracaat ediyor, onlardan medet umuyor. Sonra halkı toplayarak millî galeyanı önlemek istiyor. Bunu da kâfi görmeyerek bizi öz kardeşlerimizle boğuşturmak çarelerini arıyor. Bunu davetine müsaade talebinde bulunduğu genç ve tecrübesiz vatandaşları silahlandırarak üzerimize göndermeğe kalkışıyordu." Cebesoy, a.g.e., s. 236.

${ }^{57}$ TITE Arşivi., Kutu No: 21, Belge No: 16-3001

${ }^{58}$ Cebesoy, a.g.e., s. 237.

${ }^{59}$ TÍTE Arşivi, Kutu No: 307, Belge No: 12.

${ }^{60}$ Özçelik, a.g.e., s. 99. 
bir telgraf göndererek "Milletin İradesi'nin önünde durulamayacağını ve milli arzuya tabi olmalarını... ${ }^{61}$ " keskin bir dille istedi.

Mutasarrıf Hilmi Bey, Mustafa Kemal Paşa'dan aldığı bu ültimatom niteliğinde telgraftan hemen sonra Dahiliye nezareti'ne şifreli bir telgraf çekti. Heyet-i Temsiliye adına Mustafa Kemal Paşa'nın tebliğinden de bahsettikten sonra Kuva-yı Milliye'nin olası kent merkezine yönelik bir hareketine karşı yegâne dayanak noktasının ișgalci İngiliz kuvvetleri olduğunu vurguladı ${ }^{62}$. Aynı gün livaya bağlı Seyitgazi ${ }^{63}$ ve Çifteler'in ${ }^{64}$ Sivas Kongresi kararlarına uyarak İstanbul ile haberleşmeye son vermeyen liva merkezi ile bağlantılarını kesmesi mutasarrıfı iyice telaşlandırdı. O'na göre bu ortamda tek kurtuluş çaresi milliyetçilerle İngilizlerin çarpışmasıydı. Panik ve korku içerisindeki Mutasarrıf Hilmi Bey, başta Dâhiliye Nezareti olmak üzere, aklına gelebilecek her yere, tutunabileceği her makama, telgraf üzerine telgraf yazarak, benzer istekleri tekrarladı. Bu telgraflaşmalardan anlaşıllyordu ki, Mutasarrıf, İngiliz kontrol subayı ve kolordu komutanı Kiraz Hamdi Paşa aralarında anlaşamamışlardı. Yani, Heyet-i Temsiliye'nin yapmış olduğu sert ve açık tebligat bu üç makamı birbirinden ayırmıştı. Eğer birlikte hareket edebilselerdi, Kuva-yı Milliye'nin bu ilk milli girişimi zorluklarla karşılaşabilirdi ${ }^{65}$.

\section{D- Korkunun Yarattığı Bir Girişim: Eskişehir'de Sıkıyönetim İlanı:}

İstanbul Hükümetleri ile Kuva-yı Milliye'nin Eskişehir üzerindeki nüfuz mücadelesi kentte her geçen gün ağırlı̆̆ını hissettirmekteydi. Harbiye Nazırı Süleyman Şefik Paşa'nın başlangıçta Eskişehir'de bir Asayiş Livası'nın kurulması için bölgede İstanbul'un atadığı komutan Kiraz Hamdi Paşa'ya talimat vermesi ${ }^{66}$ ve İngilizlerden de her türlü kolaylığın

61 “...Ya bu telgrafi alır almaz sizin de bir millet ferdi olmak üzere hemen milli arzuya tabi olmanızı ve milli kongre tebligatına uyarak mevcut hükümet ile irtibatınızı keserek bütün işlerinizde Heyet-i Temsiliye'ye müracaat etmenizi ihtar ederiz. Aksi takdirde milli arzuya küçük bir zaman bile mukavemet edemeyeceksiniz, zât-1 âlilerinden milli arzuya uymanızı rica ederiz . 17 Eylül 1335 [1919] Milli Kongre Heyet-i Temsiliyesi namına Mustafa Kemal" TíTE Arşivi., Kutu No: 21, Belge No: 16-3001-4001; Atatürk'ün Tamim, Telgraf ve Beyannameleri, c. IV, s. 74; Atatürk'ün Bütün Eserleri, (1919), c. IV, s. 62.

${ }^{62}$ TíTE Arşivi., Kutu No: 21, Belge No: 16-4001; Cebesoy, a.g.e., s. 237-238.

${ }^{63}$ TíTE Arşivi., Kutu No: 307, Belge No: 19.

${ }^{64}$ TíTE Arşivi., Kutu No: 21, Belge No: 16-5001.

${ }^{65}$ Cebesoy, a.g.e., s. 240.

${ }^{66}$ İstanbul Hükümetleri ve onların Eskişehir'deki temsilcilerinin tüm çabalarına rağmen “Asayiş Livası” kurulamadı. Çünkü Eskişehir halkı Milli Mücadeleye karşı oluşturulmaya çalışılan bu birliklere katılmadı. Ve 6 Ekim 335/1919 tarih ve 5733 numaralı emirle “Asayiş 
gösterilmesinin istenmesi bu mücadelenin zor geçeceğinin en önemli işaretleriydi. Bu süreç içerisinde başka bir girişim de doğrudan hükümetten geldi. Damat Ferit Paşa, Üçüncü Hükümet döneminin son günlerinde(20 Eylül 1919) Padişaha imzalattığı beyannameyi ${ }^{67}$ yayınlayarak, milletin azim ve gayretini uyuşturmak istedi. Beyannamenin parlak cümleleri altındaki gizli anlamlarda Kuva-yı Milliye'nin etkinlikleri eleştirilmekte, halkın bu eylemlere destek vermesi engellenerek, Millet ile onun içerisinden çıkan Kuva-yı Milliye ayrıştırılmaya çalışılmaktayd ${ }^{68}$. Bu nedenle "Beyanname-i Hümayun" un yayınlanmasından sonra Eskişehir'in içerisi daha yoğun faaliyetlere sahne oldu. Milli Mücadele'ye karşıt cephenin temsilcileri tekrar harekete geçti. Mutasarrıf Hilmi Bey, Komutan Kiraz Hamdi Paşa ve bölgedeki İngiliz işgal komutanı General Solly Flood telgrafhanede buluşarak İstanbul ile uzun süre görüştü. 22 Eylül'de mutasarrıf ve Jandarma kumandanı bir yolunu bularak Çifteler ve Seyitgazi Nahiyeleri ile temas sağladı. Şifre ile yapılan görüşmelerde İngiliz kuvvetlerinin kendileriyle beraber olduklarını, Eskişehir halkının da kendilerine katıldıklarını belirten mutasarrıf, asilerin yani Millicilerin ellerinin ve ayaklarının bağlanarak Eskişehir'e gönderilmelerini, bu mümkün olmazsa öldürülmelerini istedi. Ancak bu bölgelerden beklediği yanıtı alamadi ${ }^{69}$.

Bunun üzerine Mutasarrıf Hilmi Bey, Dâhiliye Nezareti'ne gönderdiği 22 Eylül 1335/1919'tarih ve 195 numaralı telgrafla, şehirde güvenlik ve asayişin sağlanması, halkın işine dönmesi için liva genelinde “İdare-i Örfiye"(Sıkıyönetim) nin ilanına izin istedi ${ }^{70}$. Ancak hükümet bu izni vermede ağır davrandı.

Mutasarrıf Hilmi'nin baskılarından bunalmış olan Eskişehir'deki Kuva-yı Milliye yanlıları bu duruma son vermek ve mutasarrıfı değiştirmek için 28 Eylül 1919'da mutasarrıfı değiştirmek için harekete geçti. Ancak başarılı olamadılar ${ }^{71}$. Mustafa Kemal Paşa yapılan bu girişimleri şu sözlerle dile getirmekteydi" ${ }^{72}$ : "Eskişehir Mutasarrıfının hain Ferit Paşa hükümetinin hidmetkârı olmakta devam eylemesi, İngilizlerin Eskişehir'deki kuvvetlerini hissolunur derecede tezyide kıyam eylemeleri, o civar halkı muhikk olarak

Livası" nın kurulmasından vazgeçildi. Genkur. ATASE Arşivi, İSH, Kutu No:29, Gömlek No: 99; ATASE Arșivi, İSH, Kutu No:61, Gömlek No: 114.

${ }^{67}$ Padişah beyannamesi için bkz. Gazi Mustafa Kemal Atatürk, Nutuk/Söylev, Vesikalar/Belgeler, c. III, TTK, Ankara: 1989, s. 1400-1403, Belge 98.

${ }^{68}$ Türk İstiklal Harbi II. Cilt, Batı Cephesi 2nci Kısım, s. 96; Cebesoy, a.g.e., s.

251; Atatürk, y.a.g. b., s. 1401.

${ }^{69}$ Cebesoy, a.g.e., s. 252.

${ }^{70}$ Başbakanlık Osmanlı Arşivi, DH. KMS, Dosya No: 53-3, Vesika No: 32.

${ }^{71}$ Türk İstiklal Harbi II. Cilt, Batı Cephesi 2nci Kısım, s. 95-96.

${ }^{72}$ Genkur. ATASE Arşivi, İSH, Kutu No: 346, Gömlek No: 70. 
teessüre düşürmüş olduğundan, ... bir çok silahlı kuvvetler Eskişehir Hükümeti aleyhinde harekat eylemişlerdir.....".

$\mathrm{Bu}$ arada Mutasarrıf Hilmi Bey'in Dahiliye Nezareti'ne gönderdiği Eskişehir'de S1kıyönetim ilan edilmesiyle ilgili isteğinin üzerinden bir hafta geçmesine rağmen İstanbul'dan yanıt gelmemişti. Fakat Eskişehir ve çevresinde Kuva-yı Milliye ile İstanbul Hükümeti/İşgal Kuvvetleri mücadelesi büyük bir ivme ile devam ediyordu. Kuva-yı Milliyeciler, Hilmi Bey'e gönderdikleri telgraflarda, İstanbul'la irtibatı keserek Eskişehir'i Kongreye bağlamasını veya vakit kaybetmeden trenle İstanbul'a gitmesini son kez ihtar etmekteydi ${ }^{73}$. Liva merkezinde meydana gelen olaylar sonucunda Kiraz Hamdi Paşa, 29 Eylül 335/1919'da Harbiye Nezareti'ne bir telgraf göndererek, " Eskişehir'de mevcutları elli kadar olan muhaliflerin propagandaları halk üzerinde heyecana neden olduğundan, Mutasarrıfın 30 Eylül'de İdare-i Vilayet Kanunu'nun 28. maddesine istinaden sıkıyönetim ilan edeceğini bildirdi ${ }^{74}$. Gerçekten de Mutasarrıf Hilmi Bey'in girişimleri sonucunda Eskişehir Hükümet Meclisi, belirtilen maddeye dayanarak Eskişehir ve çevresinde geçici olarak Sıkıyönetim ilan etti ${ }^{75}$.

20 Eylül 1293/ 2 Ekim 1877 tarihli İdare-i Örfiye Kararnamesi'ne eklenilen 18 Eylül 1335/ 18 Eylül 1919 tarihli Kararname-i Ahire ${ }^{76}$ gereğince oluşturulması gereken İdare-i Örfiye Divan-1 Harbine(S1kıyönetim Mahkemesi) seçilenler şunlard1 ${ }^{77}$ :

Örfi İdare Divan-1 Harp Reisliğine (S1kıyönetim Mahkemesi Başkanlığına)

- Sabık(Eski) İstanbul Muhafızı Mirliva Seyit Paşa,

Azalar(Üyeler) :

- Eskişehir Ahz-1 Asker Kalemi Divan-1 Harp Reisi Kaymakam İbrahim,

- Sabık Beyrut Divan-1 Harbi Örfi Reisi mütekayyidiyeden(emekli) Kaymakam Hilmi Bey,

${ }^{73}$ B.O.A.,DH. KMS., Dosya No: 57-2, Vesika No: 28' den aktaran Güneş-Yakut, a.g.e., s. 173 .

${ }^{74}$ ATASE Arş., K1. 185,D.(20) 90, Fh. 180'den aktaran Sarıkoyuncu vd., a.g.e., s. 35.

75 “Eskişehir' den Harbiye Nezaretine Mevrud Şifredir

Eskişehir Hükümet-i Mahalliyesi Sıkıyönetim ilan etti..." Genkur. ATASE Arşivi, İSH, Kutu No:196, Gömlek No: 276; BOA., DH, KMS, Dosya No: 53-3, Vesika No: 55; BOA., DH. ŞFR, Dosya No: 103, Vesika No: 16;

${ }^{76}$ Genkur. ATASE Arşivi, İSH, Kutu No:242, Gömlek No: 84; Genkur. ATASE Arşivi, İSH, Kutu No:225, Gömlek No: 157.

${ }^{77}$ Genkur. ATASE Arşivi, İSH, Kutu No:196, Gömlek No: 276 
- Eskişehir Ahz-1 Asker Kalemi Divan-1 Harp Azasından Binbaşı Ethem Bey,

- 5. Kolordu İkinci Kısım Amiri Binbaşı Vehbi Efendi

Mutasarrıf Hilmi Bey'in Sıkıyönetim ilanının hemen arkasından o zamana kadar kimsenin katılmadığı Asayiş Livası'nı oluşturabilmek amacıyla, 1303 ve 1309 doğumluların üç güne kadar şubelere müracaatları istendi. Bu kişilerden piyade olacaklara 1500 Kuruş, süvari olacaklara 2500 Kuruş aylık verileceği duyuruldu ${ }^{78}$.

\section{E- Eskişehir'in Heyet-i Temsiliye'ye Bağlanması}

Mutasarrıf Hilmi Bey'in Kuva-yı Milliye aleyhindeki bu çalışmaları artarak devam ederken, halkın mutasarrıfa karşı girişimlerinin sonuçsuz kalması fedakâr Eskişehirlileri yıldırmadı. 1 Ekim'i 2 Ekim'e bağlayan gece başlayan yeni bir girişim, 2 Ekim günü büyük bir kalabalığın toplanmasıyla sonuçland. $\mathrm{Bu}$ tarihte Damat Ferit hükümetinin iktidardan çekilmesi olayların daha fazla büyümesine engel oldu. Yeni kurulan Ali Rıza Paşa Kabinesi'nde mili mücadeleden yana olan insanların da bulunması umutları $\operatorname{artırd1}^{79}$. 3 Ekim 1919'da Eskişehir'de Kuva-yı Milliye yanlıları duruma hâkim oldu. Aynı tarihte Ali Fuat Paşa, Eskişehir Belediye Reisi Bayraktar Hacı Veli Efendi ve Eskişehir Muhasebeciliğine gönderdiği mektupta yapılması gerekenleri bildirdi. Buna göre ${ }^{80}$ :

1- Anadolu'nun birçok vilayeti Milli Kongreye bağlanmışken Eskişehir bu yönde geride kalmıştır. Ancak Eskişehir'in Milli Kongreye bağlanması yönündeki azminiz önünde hiçbir şey engel olamayacaktır.

2- Mutasarrıf Hilmi Bey, Kolordu Komutanı Hamdi Paşa, Kadı Efendi, Merkez Polis Memuru Necati Efendi, Muhasebe-i Hususiye Müdürü Mustafa Efendi, eski belediye başkanı Mehmet Ali Bey, İtidal Gazetesi yönetiminden Burhanettin Efendi ve Cephane Memuru Mülazım Hayri Efendi've milli emellere aykırı hareket ettiği bilinenlerin tutuklanması,

3-Yeni kabine tarafindan atama yapılıncaya kadar Kongre Heyet-i Temsiliyesince Mutasarrıflı̆ga Muhasebeci(Sabri) Bey'in, Mevkii Kumandanlığına vekâleten Binbaşı Mehdi Bey'in getirilmesi,

4- $\mathrm{Bu}$ işler gerçekleştirilirken Liva Muhasebeci Sabri Bey ile iştişare edilmesi istenilmekteydi.

${ }^{78}$ BOA., DH, SSM, Dosya No: 38, Vesika No: 14.

${ }^{79}$ Cebesoy, a.g.e., s. 252; Türk İstiklal Harbi II. Cilt, Batı Cephesi 2nci Kısım, s. 97; Sarıkoyuncu vd., a.g.e., s. 37.

${ }^{80}$ TÍTEA., Kutu No: 312, Belge No: 3. 
Kuva-y1 Milliye nin arzusu halkın desteğiyle vilayet muhasebecisi Çolakoğlu Sabri Bey 3 Ekim 1919'da vekâleten mutasarrıflığa getirildi. İkili yapı bir gün sürdü. 4 Ekim'de Mutasarrıf Hilmi Bey'in öldürülmesinden sonra Kuva-yı Milliye duruma tamamen egemen oldu ${ }^{81}$

\section{F- Mutasarrıf Hilmi Bey'in Öldürülmesi}

Eskişehir'de Eylül ayı ortalarından itibaren artan Ulusalcı-İstanbul Hükümeti mücadelesi Mutasarrıf Hilmi Bey'in işbirlikçi tavırları nedeniyle oldukça kritik bir hale geldi. Mutasarrıf Hilmi Bey'in, kentte asayiş ve güvenin sağlanması için Dâhiliye Nezaretinden onay almaksızın İdare-i Örfiye(S1kıyönetim) ilanı, durumu oldukça gergin hale getirdi. Ortaya çıkan bu yeni durumdan Mutasarrif Hilmi Bey en üst derecede yararlanmaya çalıştı. Bir taraftan Asayiş Livası'nın oluşturulmasına çalışılırken diğer taraftan büyük paralar harcanarak Kuva-yı Milliye ile mücadele etmek için farklı teşkilat girişimlerinde de bulundu. Nitekim bu doğrultuda, Kiraz Hamdi Paşa'nın biraderi Jandarma Kaymakamlığından uzaklaştırılmış Faik Bey'in rütbesi iade edilerek ve onun emrinde gizli bir teşkilat kurulmaya başland1. Oluşturulmaya çalışılan bu kuruluşun temel amacı, Ali Fuat Cebesoy ve arkadaşlarını ölü veya diri ele geçirmekti. Bundan başka aynı gün İngilizlerle ortaklaşa hareket edilerek suçlu veya suçsuz birçok kişi tutukland1, direnenlerden Doktor Tahsin Bey'le birkaç masum öldürüldü.

30 Eylül'e kadar, Bursa vilayetiyle, Isparta, Burdur, Denizli Sancakları, Dinar, Uşak, Gediz, Alaşehir ve Söke kazaları gibi henüz birliğe girmemiş olan Batı Anadolu'nun kalan kısmı da İstanbul Hükümeti ile bağlantılarını kesmişler ve Milli Kongreye tâbi olmuşlardı. 30 Eylül'de yalnız İstanbul, Eskişehir ve İzmit şehirlerinin resmi çehreleri istisna edilecek olursa bütün millet İstanbul Hükümeti'nden fiilen ayrılmıştı ${ }^{82}$.

İstanbul Hükümeti, 1 Ekim'de son gayret ve faaliyetleri Eskişehir'i elde tutmaya çalıştı.. Mutasarrıf Hilmi Bey, ilan ettiği sıkıö̈netimden yararlanarak halka işkence yapmaya yöneldi. Ayrıca halkı milli kuvvetlere ve kumandanlarına karşı kışkırttı. Milletin kesesinden on bin liradan fazla para harcayarak Kuva-yı Milliye ve önderlerine suikast girişimleri hazırlad $^{83}$. Eskişehir'de durum giderek gerginleşmekteydi. Yapılanlara karşı Kuva-yı Milliye de yılgınlık yoktu ve halk onların yanındaydı. Durumdan rahatsız olan Mutasarrıf Hilmi Bey 1 Teşrinievvel 1335/Ekim 1919'da Dâhiliye Nezareti'ne çektiği telgrafta Eskişehir'deki gelişmeleri anlatmak

\footnotetext{
${ }^{81}$ Güneş-Yakut, a.g.e., s. 177.

${ }^{82}$ Cebesoy, a.g.e., s. 262.

${ }^{83}$ Cebesoy, a.g.e., s. 263.
} 
için yerine Kolordu komutanını vekil bırakarak o gün veya ertesi gün İstanbul'a gelmesi için izin verilmesini istedi ${ }^{84}$.

Ancak Mutasarrıf Hilmi Bey’e Dâhiliye Nezareti'nden aynı gün verilen yanıtta, "böylesi önemli bir zamanda bir gün için bile olsa livayı terk etmeniz münasip olamaz, beyanatınızdan ibaret ise şifre ile bildiriniz ${ }^{85}$, denilmekteydi. Ama bu çekinme ve korkularına rağmen Hilmi Bey Eskişehir halkına eziyetten de geri durmadi.

Eskişehir'de göreve başladığı andan 3 Ekim tarihine kadar Kuva-yı Milliye ye karşı her firsattan yararlanarak Milli hareketi bastırmaya çalışan Hilmi Bey, Damat Ferit Kabinesi'nin istifasıyla birlikte halk tarafindan mutasarrıflıktan alındı. Yerine Çolakoğlu Sabri Bey Mutasarrıf seçildi. Ancak Mutasarrıf Hilmi Bey görevinden ayrılmadı ${ }^{86}$. Böylece kentte işler iyice karıştı ve ikili bir yönetim oluştu.

Kentte olası aleyhte bir durumda müdahalede bulunmak için kentin dışında hazırda bekleyen Kuva-yı Milliye birlikleri Eskişehir Belediye Reisi Hacı Veli Efendi tarafindan acele edilmemesi konusunda uyarıldı. Hacı Veli Efendi Kanlıpınar'da bulunan Kuva-yı Milliye'ye bir adamını göndererek, belediyede bir toplantı yapıldı ğını ve şehre şimdilik girilmemesini rica etti ${ }^{87}$.

Görevini sürdürmede 1srar eden Mutasarrıf Hilmi Bey, 4 Ekim 1919'da saat bir civarında bir jandarmanın korumasında öğle yemeği için evine giderken hükümet konağının 100-150 metre ilerisinde Akarbaşı mevkiinde silahlı saldırıya uğradı ${ }^{88}$. Yaralı olarak evine ulaşabilen Mutasarrıf Hilmi Bey, yapılan tüm müdahalelere rağmen kurtarılamadı ve olaydan birkaç saat

${ }^{84}$ BOA., DH. KMS, Dosya No: 56-1, Vesika No: 25.

${ }^{85}$ BOA., DH. KMS, Dosya No: 56-1, Vesika No: 25.

${ }^{86}$ Sarkoyuncu vd, a.g.e., s. 39.

87،“ 20. Kolordu Kumandanlığına 3 Teşrin-i evvel 335

Aşılar köprüsünün takriben bir kilometre şarkında Eskişehir'den Belediye Reisi Hacı Veli Efendi'nin göndermiş olduğu bir adama tesadüf ettik. Ferit Paşa Kabinesi sükût etmiş ise de yerine hangi kabinenin geçtiği kat'i olarak malum olmadığı ve belediye reisi nezdinde bu gün bir içtima yapılmakta olduğu ve şehre şimdilik girmemekliğimizi rica ettiklerini ifade etti. Aşıklar Köprüsü'nün garbında istihkam siperlerinde İngiliz ve Osmanlı efradı bulunduğunu ve öğle vakti gönderilecek haberi intizar etmek üzere Kanlıpınar'da bulunduğumuz maruzdur.’TíTEA., Kutu No: 312, Belge No: 4.

88 " $\mathrm{Bu}$ gün zevali saat bir raddelerinde Mutasarrıf Beye hanelerine gitmekte iken meçhul bir şahıs tarafından bir suikasd icra edilerek kurşunla bacağından ve kolundan ağır surette mecruh düştüğü ve şahsı merkumenin firar ettiği biltahkîk anlaşılmağla berây1 malumat arz olunur. 4 Teşrinievvel 335 / Eskişehir Emniyet Müfettiş Vekili Sudi” B.O.A., DH., EUM.,AYŞ., Dosya No: 24, Vesika No: 87 
sonra vefat etti ${ }^{89}$. Mutasarrıf Vekaletini ele alan Kiraz Hamdi Paşa'da korkarak trenle İstanbul'a kaçtı. Halkın isteği ile Liva Muhasebecisi Sabri Bey Vekâleten Mutasarrıflığa getirildi ${ }^{90}$. Mutasarrıf Vekili Sabri Bey, 5 Ekim 1919 'da bir bildiri yayınlayarak, izlenecek yöntem ve programı açıklad1 ${ }^{91}$.

Ali Fuat Paşa'da aynı tarihte Ankara'da 20. Kolordu Kumandanlığ 1 Vekâletine gönderdiği telgrafta, Eskişehir halkının milli amaçlara bağlandığı, Liva muhasebecisinin Mutasarrıflık makamına getirildiği, milli amaçlara muhalefet edenlerin tutuklandığ 1 , Mutasarrıf Hilmi Bey'in bir "vatansever" tarafindan öldürüldüğ̈̈nü bildirdi ${ }^{92}$

\section{G-Olayın Osmanlı Hükümeti tarafından Sorușturulması}

Eskişehir Emniyet Müfettiş Vekili'nin verdiği bilgiler dışında Mutasarrıflıktan herhangi bir bilginin İstanbul'a ulaştırılmaması üzerine, Dâhiliye Nezareti doğrudan Nâzır imzalı bir telgraf göndererek yaşanan olay ve yapılan takibatla ilgili bilgi istedi ${ }^{93}$.

Nezaretin bu kısa ve sert üsluplu telgrafı üzerine Eskişehir Mutasarrıf Vekili olayın nasıl meydana geldiğini anlatan kısa bir telgraf gönderdi ${ }^{94}$ :

Belgelere göre olay şöyle gelişti: "Mutasarrıf Hilmi Bey, 4 Ekim 1919 cumartesi günü her zaman olduğu gibi yanında Jandarma eri ile birlikte öğle yemeğine gitmek üzere saat 11.40 da hükümet konağından çıktı. Yaklaşık 100-150 metre gittikten sonra ${ }^{95}$, Akarbaşı mahallesi mevkiinde evinin civarına yaklaştı̆̆ında kimliği belirlenememiş bir kişi ilk önce koruması jandarma erine dört-beş el ateş etti ancak isabet ettiremedi. Daha sonra silahı Mutasarrıf Hilmi Bey'e yönelterek, dört el de ona ateş etti. Mutasarrıf Bey'den çıkarılan mermilerden birinin batının sağ tarafına isabet ettiği, diğerinin sol bacağının bir tarafından girip diğer taraftan çıktığı, üçüncünün cebindeki saate isabet ettiğg ${ }^{96}$ anlaşılmıştır. Yaralarına rağmen metanetini koruyan Hilmi Bey evine kadar gelebilmiş ve yatağ1 üzerine düşmüştür. Olaydan haberdar olan adliye ve sihhiye memurları Mutasarrıf Hilmi Bey'in

${ }^{89}$ B.O.A., y.a.g.b.

${ }^{90}$ TİTEA., Kutu No: 311, Belge No: 27.

${ }^{91}$ Genkur. ATASE Arşivi, İSH, Kutu No. 272, Gömlek No. 115, Belge No. 115-1; Gökbilgin, a.g.e., s. 60; Güneş-Yakut, a.g.e., s.178-179; Sarıkoyuncu vd., a.g.e., s. 37.

${ }^{92}$ TİTEA., Kutu No: 311, Belge No: 35.

${ }^{93}$ BOA., EUM, AYŞ, Dosya No: 24, Vesika No: 87

${ }^{94}$ BOA., DH., EUM., Dn. 24, Vn.87,

${ }^{95}$ BOA., DH., EUM., Dn. 57-2, Vn. 28.

${ }^{96}$ BOA., DH., EUM., Dn. 57-2, Vn. 28. 
evine ulaşmışlar, ancak aldığ 1 yaralardan dolayı Hilmi Bey, aynı gün saat beş buçuk civarında vefat etmiştir ${ }^{97}$."

Olayın üzerinden zaman geçmesine rağmen ne Jandarma, nede polis tarafından somut bir bilgiye ulaşılamaması İstanbul hükümetinde tedirginliği artırdı. Eskişehir'deki Polis ve jandarmanın bu konuda ağır davrandığ 1 ve görevini aksattığ 1 düşüncesiyle ilgili makamlara telgraflar gönderilerek katilin bir an evvel yakalanması istendi ${ }^{98}$. Bunun üzerine Eskişehir Jandarma Tabur Komutanı Hamdi Bey, beş maddeden oluşan cevabında görevini fazlasiyla yerine getirdiğini, buna rağmen polis dairesi ve askeriyenin bu olaya kayıtsız davrandığını, bunlarla ortaklaşa çalışma yapılamayacağını, fakat kendisinin görevi aksattığına dair bir şüphe varsa gereğinin yapılması istedi $^{99}$.

İstanbul Hükümeti, Eskişehir Jandarma Komutanı'ndan gelen asker ve polisin ilgisiz tavırlarını anlatan bu telgraf üzerine olayı soruşturmak için Adliye ve Mülkiye Müfettişleri görevlendirdi. Adliye ve Mülkiye Müfettişlerinin hazırladığı raporu biri başlangıç olmak üzere dört ana başlıkta özetleyebiliriz. Raporun başlangıcında bu tür cürüm olaylarını incelemenin mülkiye müfettişlerinin görevleri olmamakla beraber, emir buyrulması üzerine Dahiliye ve Adliye Nezaretlerince başlatılan soruşturmaya yerinde incelemeler yapılarak raporun hazırlandığ belirtilmektedir.

İkinci başlıkta(Katlin suret-i vukû'u) olayın oluş biçimi detaylarıyla anlatılmaktadır. Raporun üçüncü başlığında (Esbâb-1 Katl) gerçekleştirilen suikastın nedenleri incelenmiş ve olası ihtimaller üzerinde durulmuştur. Gerçekleştirilen suikastın bir namus ve intikam sorunu olmayıp, kesinlikle siyasi bir sorundan kaynaklandığı belirtilmiş olmakla birlikte, kimler tarafindan ne gibi siyasi sebeplerle olduğuna dair kesin bir bilgi elde edilemediği vurgulanmıştır. Bu başlık içerisinde özellikle Mutasarrıf Hilmi Bey'le ilgili tüm evraklar, yazışmalar ve gelen telgraflar tek tek inceleniştir. $\mathrm{Bu}$ evraklardan özellikle Heyet-i Temsiliye ve ona bağlı kişilerden gelen telgraflar üzerinde durulmuştur. Bu belgeler, milli mücadelenin Kuva-y1 Milliye döneminde harekâtın önderlerinin, yalnız silahlı güçle değil yazışmalarla(gönderilen telgraf, mektup vs.) oluşturulmaya çalışılan baskıyla da "Psikolojik Harp" taktiklerini de ustaca kullandıklarının önemli bir kanitiydi.

Ayrıca bu telgraflarda Milli Mücadele'nin amacı, yöntemi, hedefleri ile ilgili bilgileri, mücadelenin önemli dönüm noktalarındaki beyanname ve

\footnotetext{
${ }^{97}$ BOA., DH., EUM., Dn. 57-2, Vn. 28.

${ }^{98}$ BOA., DH., EUM., Dn. 57-2, Vn. 28.

${ }^{99}$ BOA, DH., KMS., D. 57-2, Vn. 28.
} 
içeriklerini, İstanbul Hükümetleri, onun yerel temsilcileri ve işgalci güçlerin yaratmaya çalıştığı dezenformasyonu/bilgi kirliliğini, milli mücadele yanlılarının karşı propagandalarına ilişkin önemli detayları da görebilmek olanakliyd1.

Müfettişlerin raporunun dördüncü başlığında (Katil Kim), katilin kimliği eşkali, tanınıp tanınmadığı, kente nereden geldiği, nerede oturduğu, ve șüphelilerin kimler olduğu üzerinde duruldu. Rapora göre Hilmi Bey'e suikast esnasında yanında bulunan Jandarma eri Mehmet Ali ile olayı yakından ve uzaktan görenler katilin evsaf ve eşkâlini tarif etmekle beraber isim ve kimliğini bilmediklerini ifade etmişlerdir. Koruma Jandarma Mehmet, katilin Eskișehirli olmayıp yabancı birisi olduğunu, fakat Eskişehir'le bir bağlantısı bulunduğunu, kentin aşağı mahallelerinden birinde oturduğunu ve olaydan bir gün evvel makama gelerek mutasarrıfın odasına girmek istediğini, tüm bu ayrıntıya rağmen kendisini tanımadığını söylediğini belirttiler.

Müfettişler, Jandarma Mehmet'in bu kadar detay bilgiler verip katilin ismini bilmediğini söylemesini mantıklı bulmadılar. Onlara göre bu jandarma er'i failin ismini biliyor, fakat bilinmeyen nedenlerden dolay bu ismi vermek istemiyordu ${ }^{100}$. Ayrica olay sonras1 Mutasarrıf Hilmi Bey'de evinde Sıhhiye ve Adliye memurlarına verdiği ifadede katili bir dereceye kadar tarif etmişti. Tanıkların verdiği eşkâldeki insanlar yakalanarak tanıklarla yüzleştirilmiş yanıtlar olumsuz olunca da serbest bırakılmıştı.

Müfettişlerin raporunda katilin kim olduğu ile ilgili olarak üzerinde en çok durulan isim Seyitgazi Nahiyesi eski müdürlerinden Süleyman Efendi'nin kardeşi Çerkes Pehlivan Şerif idi. Bu nedenle tutuklanan Pehlivan Şerif, görgü tanıklarının teşhis edememesi üzerine salıverildi. Eskişehir Mutasarrıfi da Dâhiliye Nezareti'ne yazdığı telgrafta, Müfettiș Fuat Bey’le görüştüğünü zanlı olarak gösterilen Pehlivan Şerif ile ilgili şüphelerin ortadan kalktığını ve bir başkası hakkında ipuçları elde edildiğini belirtmesine rağmen, bir gün sonra müfettişin herhangi bir bilgi vermeden Eskişehir'den ayrıldığını belirtti. Mutasarrıf ayrıca daha sonra gelen Hurşit Paşa Tahkik Heyeti'nin de konuyla ilgili birçok inceleme yapmasına rağmen bunlarında aynı şekilde hiçbir bilgi vermeden kentten ayrıldığına dikkat çekmekteydi ${ }^{101}$.

Mutasarrıf Hilmi Bey görevi başında vefat ettiği için Osmanlı Hükûmeti, ailesine 1500 Kuruş maaş başladı. Ancak ailenin bir çocuklarının yurt dışında okuması nedeniyle bağlanan aylığın azlığı hakkındaki başvurusu üzerine 3000 Kuruş'a yükseltildi. Ayrıca aynı Meclis-i Vükela kararıyla,

\footnotetext{
${ }^{100}$ BOA., DH., KMS, Dn. 57-2, Vn. 28.

${ }^{101}$ BOA., DH., KMS, Dn. 57-2, Vn. 28.
} 
Mutasarrıf Hilmi Bey'in Almanya'da okuyan oğlu için Nisan ayından itibaren öğreniminin bitimi olan Eylül ayına kadar aylık 2000 Kuruş tahsis edilerek, bu durumun Maliye ve Maarif Nezaretlerine bildirilmesine karar verildi ${ }^{102}$.

\section{H-Kuva-yı Milliyecilerin Olaya Bakışı}

Mutasarrıf Hilmi Bey'in bir suikast sonucu öldürülmesi Eskişehir'de küçük çapta bir dalgalanma meydana getirdi. Kuva-yı Milliye bu suikastı üstlenmemekle birlikte ${ }^{103}$, duruma hâkim olmakta gecikmedi. Ali Fuat Paşa'nın yönlendirmeleri ve yerinde alınan tedbirlerle kent içinde asayiş sağlanmaya çalışıldı. Merkez de sağlanan bu otorite Kuva-yı Milliye'nin çabalarıyla çok kısa bir süre içerisinde tüm çevrede de etkili oldu.

Ali Fuat Paşa, suikast olayından bir gün (5 Ekim 1919) sonra Anadoluyı Garbî Umûm Kuva-yı Milliye Başkumandanı imzasıyla yaşananları, 15. Kolordu Komutanlığına ve Heyet-i Temsiliye'ye bildirdi ${ }^{104}$. Heyet-i Temsiliye, 7 Ekim 1919 'da aldığ 1 kararla Ali Fuat Paşa'ya gösterdiği "dirayet ve kiyaset"(zeka ve anlayışl1lık, uyanıklık) den dolayı teşekküre karar verdi ${ }^{105}$.

Mutasarrıf Hilmi Bey'in öldürülmesi İstanbul basınından Süleyman Nazif tarafindan Heyet-i Temsiliye ve Mustafa Kemal Paşa'ya telgrafla bildirildi. Bunun üzerine, Heyet-i Temsiliye'de, "Katledilerek öldürülen Mutasarrif Hilmi Bey'in katillerinin takip ve yakalanması konusunda hükümetin kanuni uygulamalarına Kuva-yı Milliye'nin de yardımcı olacağına ve bu gibi eylemlerin acı ve üzüntü verdiğini" içeren bir telgrafin Nazif Bey’e iletilmesini kararlaştırdı ${ }^{106}$.

Mustafa Kemal Paşa ise 12 Ekim 1919'da Nazif Bey'e, şu telgrafı çekti:

"Hilmi Bey merhumu tanımıyoruz. Kendisini katledenlerle hiçbir alakamı yoktur ve olamaz. Hadise-i katl hakkında aldığımı malumat, teşebbüsat ve hareket-i milliyeye muhalefetten dolayl müfrit bir milliyetperver tarafindan katledildiğinden ibarettir.

${ }^{102}$ BOA., Meclis-i Vükela Mazbataları, Dn: 218, Gn: 152; Düstur, Tertîb-i sani, c. XII, İstanbul: 1927, s. 73

${ }^{103}$ Güneş- Yakut, a.g.e., s. 176.

${ }^{104}$ Karabekir, a.g.e., s. 320.

105 "Eskişehir vaziyetinin arzuy-1 millîye muvafik bir şekle girdiğini bildiren Yirminci Kolordu Kumandanı Ali Fuat Paşa'nın ibraz buyurdukları dirâyet ve ve kiyâsetten dolayı teşekküre karar verildi” Baykal, a.g.e., s. 14.

${ }^{106}$ Baykal, a.g.e., s. 17. 
Her türlü fezayih ve cinayet erbabinın takip ve derdestine hükümetin teşebbüsat ve icraat-ı kanuniyesine Kuva-yı Milliyenin bütün mevcudiyetiyle muavenet edeceği tabiìdir

Bu gibi efalden bizim dahi sizin gibi müteessir ve müteellim olmakta bulunduğumuzun beyanını zait addeyleriz ${ }^{107}$,.

Böylece Heyet-i Temsiliye ve Mustafa Kemal Paşa, açıkça olayı kınadıklarını ve olayın aydınlatılması için gereken her türlü yardımın yapılacağını bildirdi. Bu düşünceler İstanbul basınına da duyuruldu.

Mutasarrıf Hilmi Bey'in öldürülmesi olayına Kuva-yı Milliye'nin yaklaşımı ile ilgili ilginç bazı detaylar da Adliye ve Mülkiye müfettişlerinin

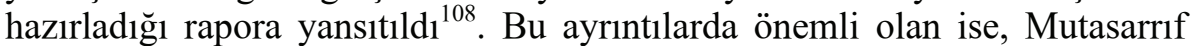
Hilmi Bey'in öldürülmesi olayının Heyet-i Temsiliye nin bilgisi dışında olduğu konusunda Merkezi Hükümetin görevlendirdiği Müfettişlerin de hem fikir olmasiydi.

\section{SONUÇ}

Eskişehir stratejik konumu nedeniyle, Milli Mücadele sürecinde hem Milliciler, hem Hükümet ve onun işbirlikçileri ve hem de İngilizler için önemli bir merkezdi. Bu durumun farkında olan Damat Ferit Hükümeti, her açıdan kendilerine bağlı Mustafa Hilmi Bey’i Eskişehir Mutasarrıflığına atadı. Göreve geldiği andan itibaren müthiş bir Kuva-yı Milliye düşmanlığg yapan Hilmi Bey, kentte bu tarz girişimlere göz açtırmadı. Anadolu'nun büyük bir kısmı Kuva-yı Milliye' ye katıldığı halde, Eskişehir'de Hilmi

${ }^{107}$ Atatürk’ün Tamim, Telgraf ve Beyannameleri, c. 4, s. 113.

108 “Mutasarrıf Hilmi Bey'in katlini müteakip isim ve hüviyeti ve kimin tarafından gönderildiği anlaşılmayan bir şahsın Eskişehir civarında bulunan 20. KO kumandanı Ali Fuat Paşa nezdine gittiği ve paşanın ikametgâhına takarrüb ettiği esnada karşısına çıkan Eskişehir'in Milli Kongre Murahhası ve Belediye Reisi Hacı Veli Efendi'nin mahdumu Hüseyin Efendi tarafından esbab-1 vürudu sual edilmesi üzerine kulağına bir şey söyleyen şahsı merkume çıkarup bir lira bahşiş verdiği ve bunu müteakib Ali Fuat Paşa nezdine girüp yine kulağına bir șey söyledikten sonra Paşayı müşarülileyh dönüp huzzara hitaben "Eskişehir Mutasarrıfı katledilmiş, fakat iyi yapmamışlar. Biz böyle kan dökülmesini istemezdik. Şimdi Milli Kongre Heyet-i Temsiliyesine ne cevap vereceğiz. Her ne ise olmuş bir şey" diye beyanatta bulunduğu da suret-i mevsukede istihbar kılınmış olmasına nazaran fail-i katl Milli Kongre'nin malumatı olmaksızın oraya mensubiyet iddiasında bulunan birkaç şahıs tarafından tertip olunduğu istidlal olunmaktadır." BOA., DH., KMS, Dn. 57-2, Vn. 28. 
Bey'in baskı ve uygulamaları nedeniyle İstanbul ile haberleşmenin kesilmesi ve Heyet-i Temsiliye'ye bağlanma bir türlü gerçekleşmedi.

Eskişehir'deki İngiliz birliklerinin sayısını giderek artırması, Mutasarrıf Hilmi Bey'in İngiliz işgal kuvvetleriyle iş birliği yapması kentte Kuva-yı Milliyeciler üzerinde baskının artmasına neden oldu. Heyet-i Temsiliye tarafindan Batı Anadolu Umûm Kuva-yı Milliye Komutanlığı'na atanan Ali Fuat Paşa'nın birlikleriyle Ankara'dan hareketle Polatlı üzerinden Sivrihisar'a gelmesi, hem Mutasarrıf Hilmi Bey'i, hem de Kolordusuz kolordu komutanı Kiraz Hamdi Paşa'yı korkuttu. Bunlar, açık bir şekilde Kuva-yı Milliye'ye karşı, İngiliz işgal kuvvetlerinden yararlanma yollarını aramaya koyuldular. $\mathrm{Bu}$ doğrultu da görüşmeler yaptılar ve kentteki hükümet baskısını daha da arttırdılar.

Eskişehir üzerinde tam bir nüfuz mücadelesi yaşanmaktaydı. Bir tarafta Mutasarrıf Hilmi Bey ve Kiraz Hamdi Paşa, diğer tarafta her geçen gün etkinliği, sayısı artan Kuva-yı Milliye. Mutasarrıf Hilmi Bey, Kuva-yı Milliye'nin kentteki hâkimiyetinin giderek artması üzerine, durumu despotik yöntemlerle kontrol edebilmek amaciyla, hükümetten onay almaksızın Eskişehir'de sıkıönetim ilan etti. Fakat bu süreçte Damat Ferit Paşa Hükümeti'nin istifası, yerine Ali Rıza Paşa Hükümetinin kurulması, Kuva-yı Milliye'nin etkinliğini daha da artırdı. 3 Ekim 1919'da Kuva-yı Milliye Eskişehir'e hâkim oldu ve Hilmi Bey'i mutasarrıflıktan aldı. Halkın desteği ile vilayet muhasebecisi Çolakoğlu Sabri Bey vekâleten mutasarrıflığa getirildi. Fakat Mutasarrıf Hilmi Bey görevini bırakmadı. Bu da kentte gerginliği daha da arttırdı.

İşte böylesi bir ortamda Mutasarrıf Hilmi Bey, 4 Ekim 1919 günü öğle yemeği için evine giderken vuruldu. Olayla ilgili bir takım isimlerin öne çıkmasına rağmen, katil yakalanamadı. Böylece bir gün süren ikili yapıdan sonra Kuva-y1 Milliye kent merkezine tümüyle egemen oldu. 


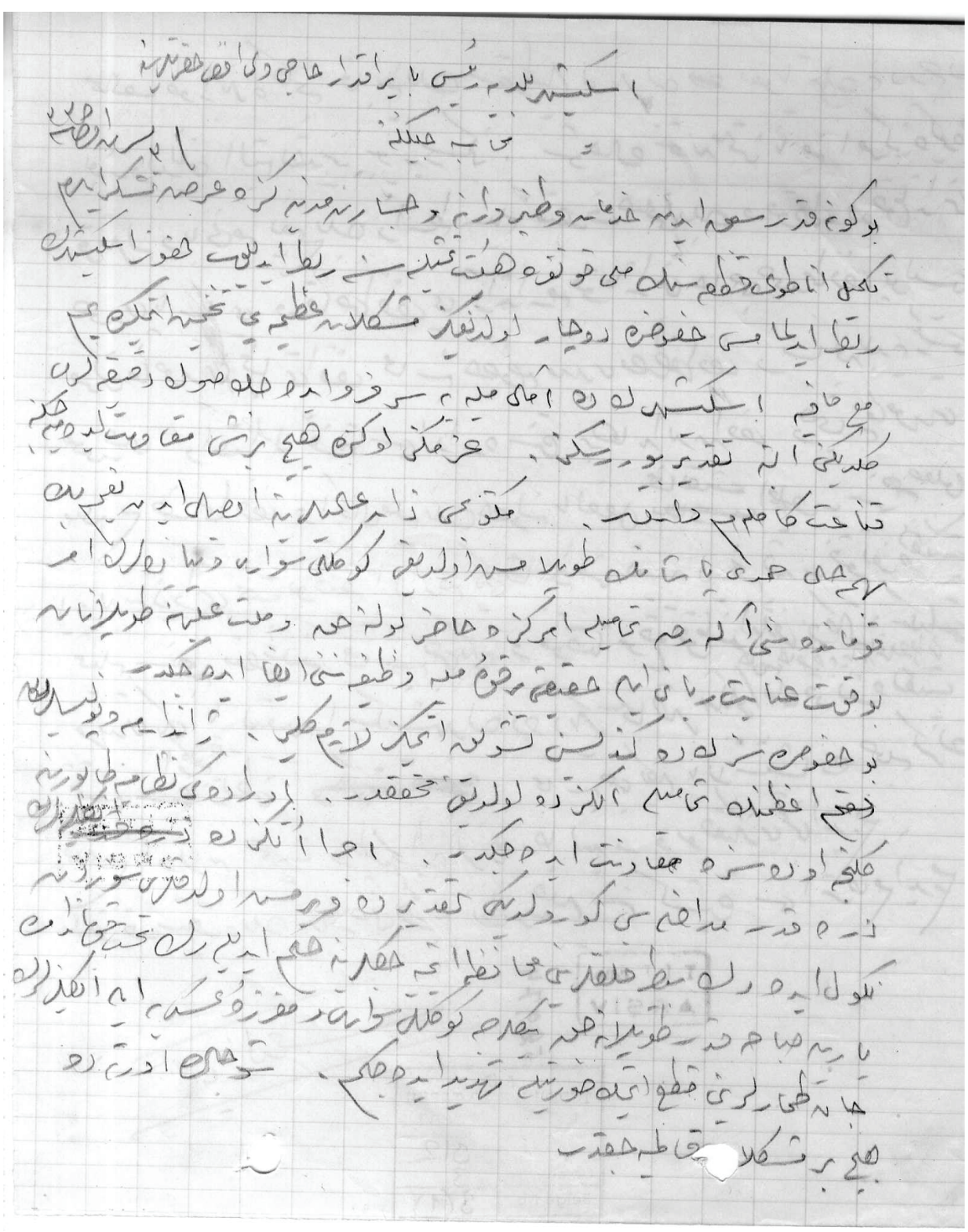

TITEA., Kutu No: 312, Belge No: 3.

Eskişehir'in Kuva-yı Milliye'nin denetimine geçtikten sonra burada yapılması gerekenlerle ilgili, Ali Fuat Paşa'nın Belediye Reisi Hacı Veli efendi ve Eskişehir Muhasebeciliğine gönderdiği mektup 


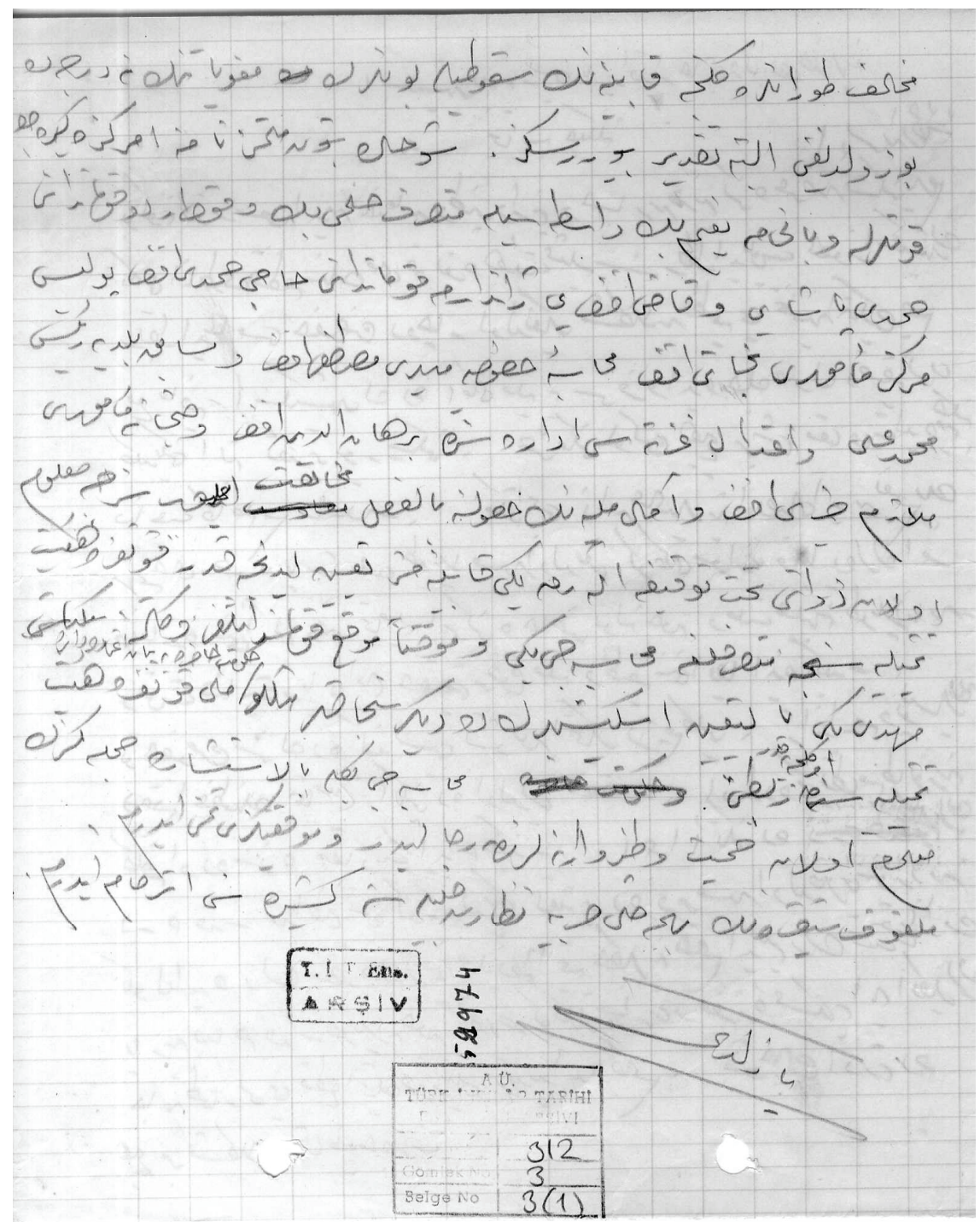

TITEA., Kutu No: 312, Belge No: 3.

Eskişehir'in Kuva-yı Milliye'nin denetimine geçtikten sonra burada yapılması gerekenlerle ilgili, Ali Fuat Paşa'nın Belediye Reisi Hacı Veli efendi ve Eskişehir Muhasebeciliğine gönderdiği mektup 


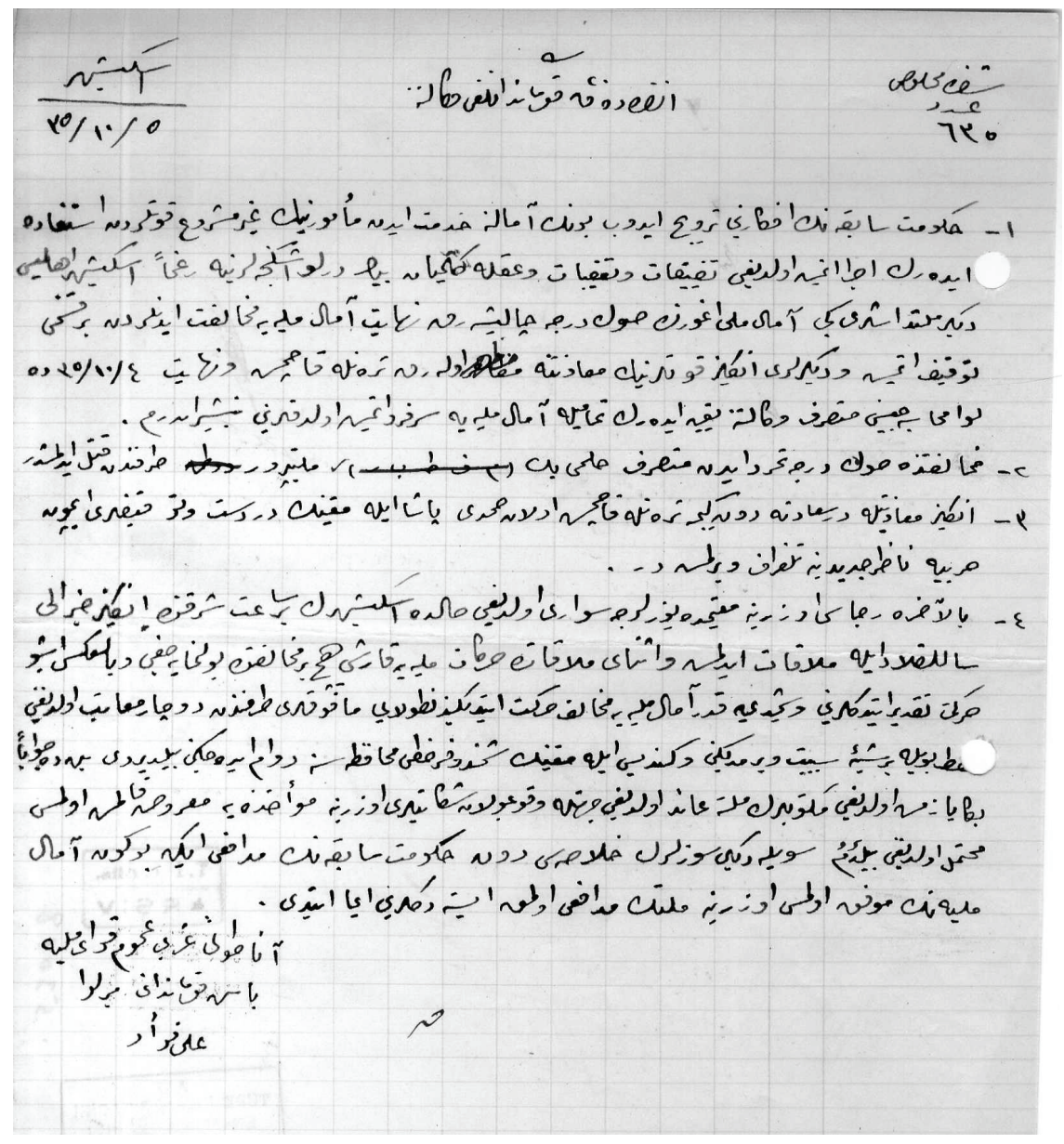

TITEA., Kutu No: 311, Belge No: 35

Ali Fuat Paşa'nın 5 Ekim 1919 tarihi itibarıyla Eskişehir'deki durumu Ankara'da 20. Kolordu Komutanlığı Vekâletine bildiren yazısı 


\section{KAYNAKÇA}

\section{A- BELGESEL KAYNAKLAR}

B.O.A., DH., EUM.,AYŞ., Dosya No: 24, Vesika No: 87

Başbakanlık Osmanlı Arşivi, DH. KMS, Dosya No: 53-3, Vesika No: 32.

BOA., DH, KMS, Dosya No: 53-3, Vesika No: 55

BOA., DH, SSM, Dosya No: 38, Vesika No: 14.

BOA., DH. KMS, Dosya No: 56-1, Vesika No: 25.

BOA., DH. KMS, Dosya No: 53-3, Vesika No: 55

BOA., DH. ŞFR, Dosya No: 103, Vesika No: 16;

BOA., DH., EUM., Dn. 24, Vn.87,

BOA., DH., EUM., Dn. 57-2, Vn. 28.

BOA., EUM, AYŞ, Dosya No: 24, Vesika No: 87

BOA., Meclis-i Vükela Mazbataları, Dn: 218, Gn: 152

Düstur, Tertîb-i sani, c. XII, İstanbul: 1927

Gazi Mustafa Kemal Atatürk, Nutuk/Söylev, Vesikalar/Belgeler, c. III, TTK, Ankara: 1989

Genkur. ATASE Arşivi, İSH Kutu No: 40, Gömlek No: 128

Genkur. ATASE Arşivi, İSH, Kutu No. 272, Gömlek No. 115, Belge No. 115-1

Genkur. ATASE Arşivi, İSH, Kutu No: 103, Gömlek No: 34.

Genkur. ATASE Arşivi, İSH, Kutu No: 195, Gömlek No: 146

Genkur. ATASE Arşivi, İSH, Kutu No: 195, Gömlek No: 265.

Genkur. ATASE Arşivi, İSH, Kutu No: 195, Gömlek No: 30

Genkur. ATASE Arşivi, İSH, Kutu No: 346, Gömlek No: 70.

Genkur. ATASE Arşivi, İSH, Kutu No: 40, Gömlek No: 119

Genkur. ATASE Arşivi, İSH, Kutu No: 40, Gömlek No: 129.

Genkur. ATASE Arşivi, İSH, Kutu No:196, Gömlek No: 276

Genkur. ATASE Arşivi, İSH, Kutu No:225, Gömlek No: 157.

Genkur. ATASE Arşivi, İSH, Kutu No:242, Gömlek No: 84 
Genkur. ATASE Arşivi, İSH, Kutu No:29, Gömlek No: 99

Genkur. ATASE Arşivi, İSH, Kutu No:61, Gömlek No: 114.

TíTE Arşivi, Kutu No: 307, Belge No: 12.

TíTE Arşivi., Kutu No: 21, Belge No: 16-2001.

TİTE Arşivi., Kutu No: 21, Belge No: 16-3001

TİTE Arşivi., Kutu No: 21, Belge No: 16-4001

TİTE Arşivi., Kutu No: 21, Belge No: 16-5001.

TİTE Arşivi., Kutu No: 307, Belge No: 19.

TİTEA., Kutu No: 311, Belge No: 27.

TİTEA., Kutu No: 311, Belge No: 35.

TíTEA., Kutu No: 312, Belge No: 3.

\section{ANILAR VE ARAŞTIRMALAR}

Arıburnu, Kemal; Milli Mücadelede İstanbul Mitingleri, Yeni Desen Matbaası, Ankara: 1975.

Atatürk’ün Bütün Eserleri, c. 3, Kaynak yayınları, İstanbul: 2000.

Baykal, Bekir Sıtkı; Heyet-i Temsiliye Kararları, TTK, Ankara: 1989

Cumhuriyetin 15. Yılında Eskişehir, İstanbul: 1938

Çankaya, Mücellidoğlu Ali; Son Asır Türk Tarihinin Önemli Olayları ile Birlikte Yeni Mülkiye ve Mülkiyeliler (1860-1923), c. 3, Ankara: 1968

Darkot, Besim; “ Eskişehir ", İslam Ansiklopedisi, Milli Eğitim Bakanlığı Yayınlar1, İstanbul:1964

Earle,Edward Mead; Bağdat Demiryolu Savaşı, (Çev: Kasım Yargıcı), Milliyet Yayınlar1, İstanbul: 1972;

Efe, Ayla; Eskişehir Demiryolu, (Basılmamış Yüksek Lisans Tezi), Anadolu Üniversitesi Sosyal Bilimler Enstitüsü, Eskişehir: 1998.

Engin,Vahdettin; Rumeli Demiryolları, Eren Yayınları, İstanbul:1993

Erdeha, Kamil; Milli Mücadelede Vilayetler ve Valiler, Remzi Kitabevi, İstanbul 1975.

Erendil, Muzaffer; “Atatürkçü Uygulamada Milli Güç”, Atatürk Araştırma Merkezi Dergisi, c. V, Mart 1989, S. 14, 
Ertin, Gaye; Eskişehir Kentinde Yerleşmenin Evrimi, Anadolu Üniversitesi Yayınları, Eskişehir: 1994

"Eskişehir", Yurt Ansiklopedisi, c.4, Anakra:1968

Goloğlu, Mahmut; Milli mücadele Tarihi II: Sivas Kongresi, İş Bankası Kültür Yayınları, İstanbul: 2008

Gökbilgin, Tayyib; Milli Mücadele Başlarken, c. 1, Türkiye İș Bankası Yayınları, Ankara: 1959

Güneş, İhsan -Kemal Yakut, Osmanlı'dan Cumhuriyet'e Eskişehir (1840-1923), Anadolu Üniversitesi Yayınları No: 1724, Edebiyat Fakültesi yayınları No: 25, Eskişehir 2007

İğdemir, Uluğ; Sivas Kongresi Tutanakları, Türk Tarih Kurumu, Ankara:1986

İnce, Celal; Eskişehir Çevre İncelemesi, İstanbul: 1969,

Jaeschke, Gothart; Kurtuluş Savaşı Kronolojisi, Türk Tarih Kurumu, Ankara: 1989

Koylu, Zafer, "XX. Yüzyılın Başlarında Eskişehir", Atatürk Araştırma Merkezi Dergisi, c. XXIV, Temmuz 2008, Sayı: 71

Koylu, Zafer; Esaretten Özgürlüğe 423 Gün, Eskişehir Ticaret Odası Yayınları, Eskișehir 2010.

Kurat, Yuluğ Tekin; Osmanlı İmparatorluğu'nun Paylaşılması, Ekonomik ve Sosyal Araştırmalar: 8, Turhan Kitabevi: Ankara 1986

Kurmuş, Orhan; Emperyalizmin Türkiye'ye Girişi, (3. Bask1), Savaş Yayınları, Ankara: 1982;

M. L. Smith, Anadolu Üzerindeki Göz, Hürriyet Yayınları, İstanbul: 1978

Oğuzoğlu, Yusuf - Feridun Emecan, “Eskişehir ”, Türkiye Diyanet Vakfı İslam Ansiklopedisi, Türkiye Diyanet Araştırmaları Merkezi, İstanbul: 1995

Olcay, Osman; Sevr Antlaşmasına Doğru (Çeşitli Konferans ve Toplantıların Tutanakları ve Bunlara ilişkin Belgeler), Ankara Üniversitesi Siyasal Bilgiler Fakültesi Yayınları No: 455, Ankara: 1981

Osmalı'dan Cumhuriyet Türkiye'sine İşçiler 1839-1950, (Derleyenler: D. Quataert-E.J. Zürcher), (Çev. Cahide Ekiz), İletişim Yayınları, İstanbul:1988.

Özsoy, Osman; Saltanattan Cumhuriyete Kurtuluş Savaşı 1918-1923; OlaylarBelgeler-Gerçekler, İstanbul Timaş Yayınları 2007.

Özyüksel, Murat; Anadolu ve Bağdat Demiryolları, Arba Yayınları, İstanbul: 1988. 
Quataert, Donald; “19. Yüzyılda Osmanlı İmparatorluğu'nda Demiryolları” Tanzimattan Cumhuriyete Türkiye Ansiklopedisi, c. 6, İletişim Yayınları, İstanbul:1985.

Quataert, Donald; Osmanlı Devleti’nde Avrupa İktisadi Yayılımı ve Direniş (1881-1908), (Çev. Sabri Tekay), Yurt Yayınları, Ankara:1987;

Rothaman, Lothar; Berlin-Bağdat, Alman Emperyalizminin Türkiye'ye Girişi, (Haz: Ragıp Zarakolu), Belge Yayınları, İstanbul:1982;

Sarıkoyuncu, Ali -Selahattin Önder-Mesut Erşan, Milli Mücadelede Eskişehir, Osmangazi Üniversitesi Yayınları, Yayın No: 072

Saruhan, Zeki; Kurtuluş Savaşı Günlüğü, c.I, Öğretmen Dünyası Yayınları, Ankara: 1984

Selek, Sabahattin; Milli Mücadele, c. I, Ankara, 1982

Sina Akşin, İstanbul Hükümetleri ve Milli Mücadele, c. I, İş Bankası Kültür Yayınları, Ankara: 1988,

Şahingöz, Mehmet; İzmir, Maraş ve İstanbul'un İşgali Üzerine Yapılan Protesto ve Mitingler, Ankara Üniversitesi Türk İnk1lâp Tarihi Enstitüsü, Yayınlanmamış Doktora Tezi, Ankara, 1986,

Tansel, Selahattin; Mondros'tan Mudanya'ya Kadar, c.2, MEB. Yay., İstanbul: 1991

Tolon, Ahmet Hurşit; Birinci Dünya Savaşı Sırasında Taksim Anlaşmaları ve Sevr'e Giden Yol, Atatürk Araştırma Merkezi, Ankara:2004;

Türk İstiklal Harbi I, Mondros Mütarekesi ve Tatbikatı, TC. Genelkurmay Başkanlığı Yayını, Ankara: 1999

Türkgeldi, Ali Fuad; Görüp İşittiklerim, TTK, Ankara:1987

Türkiye'de Yunan Vahşeti, (Çev: Yrd. Doç. Dr. Necdet Ekinci) Yeniden Anadolu Müdafaa-i Hukuk Yayınları, Antalya: 2006

Ural, Selçuk; “Ali Galip Olayının Milli Mücadele Taraftarı Gazetelerdeki (İrade-i Milliye ve Albayrak) Yankıları", Atatürk Yolu, Ankara Üniversitesi Türk İnkılâp Tarihi Enstitüsü, S. 29-30, Mayıs-Kasım 2002.

Yalazan, Em. Kur. Alb. Talat; Türkiye’de Yunan Vahşet ve Soy Kırımı (15 Mayıs 1919-9 Eylül 1922), c.1-2, TC. Genkur. ATASE Bşk. Yay., Genelkurmay Basım evi, Ankara:1994

Yıldırım, İsmail; Milli Mücadele’nin başlangıcında Eskişehir (22 Ocak 1919-20 Mart 1920), Eskişehir Büyükşehir Belediyesi Yayını, Eskişehir:1998 